\title{
Interim Progress Report - Environmental Geophysics: Building E3640 Decommissioning, Aberdeen Proving Ground, Maryland
}

Energy Systems Division Argonne National Laboratory

Operated by The University of Chicago, under Contract W-31-109-Eng-38, for the

United States Department of Energy 


\section{Argonne National Laboratory}

Argonne National Laboratory, with facilities in the states of Illinois and Idaho, is owned by the United States Government, and operated by the University of Chicago under the provisions of a contract with the Department of Energy.

This technical memo is a product of Argonne's Energy Systems (ES)

Division. For information on the division's scientific and engineering activities, contact:

Director, Energy Systems Division

Argonne National Laboratory

Argonne, Illinois 60439-4815

Telephone (708) 252-3724

Presented in this technical memo are preliminary results of ongoing work or work that is more limited in scope and depth than that described in formal reports issued by the ES Division.

Publishing support services were provided by Argonne's Information and Publishing Division.

\section{Disclaimer}

This report was prepared as an account of work sponsored by an agency of the United States Government. Neither the United States Government nor any agency thereof, nor any of their employees, makes any warranty, express or implied, or assumes any legal liability or responsibility for the accuracy, completeness, or usefulness of any information, apparatus, product, or process disclosed, or represents that its use would not infringe privately owned rights. Reference herein to any specific commercial product, process, or service by trade name, trademark, manufacturer, or otherwise, does not necessarily constitute or imply its endorsement, recommendation, or favoring by the United States Government or any agency thereof. The views and opinions of authors expressed herein do not necessarily state or reflect those of the United States Government or any agency thereof.

Reproduced directly from the best available copy.

Available to DOE and DOE contractors from the Office of Scientific and Technical Information, P.O. Box 62, Oak Ridge, TN 37831; prices available from (615) 576-8401.

Available to the public from the National Technical Information Service, U.S. Department of Commerce, 5285 Port Royal Road, Springfield, VA 22161. 


\section{DISCLAIMER}

Portions of this document may be illegible in electronic image products. Images are produced from the best available original document. 


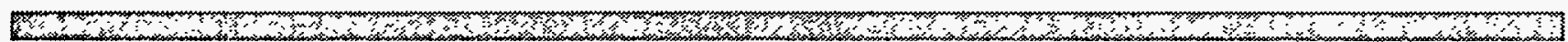

\section{Interim Progress Report - Environmental Geophysics: Building E3640 Decommissioning, Aberdeen Proving Ground, Maryland}

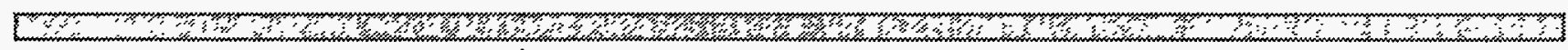

L.D. McGinnis, S.F. Miller, H.M. Borden, M.A. Benson, M.D. Thompson,

C.A. Padar, and C.R. Daudt

Center for Environmental Restoration Systems, Energy Systems Division,

Argonne National Laboratory, 9700 South Cass Avenue, Argonne, Illinois 60439

Published as

Environmental Geophysics at

Aberdeen Proving Ground, Maryland:

Building E3640

for sponsor's use only

January 1995

Work sponsored by United States Department of Defense, United States Army, Aberdeen Proving Ground, Maryland

$$
\text { DISTRIBUTION OF THIS DOCUMENT IS UNLIMITED Wh/ }
$$


This report is printed on recycled paper, with the exception of color reproductions. 


\section{Preface}

This report is one of a series on environmental geophysical studies around the perimeters of buildings in the Canal Creek area of the Edgewood area of Aberdeen Proving Ground. The series was initiated in 1991 at Building E5032, where geophysical techniques were evaluated and a design for the surveys was established. Studies continued in 1992, when surveys of Buildings E5190, E5282, E5375, E5440, E5476, E5481, E5974, and the Building E103 dump were completed. In 1993, the Argonne National Laboratory geophysics team conducted environmental surveys at Beach Point and J-Field. Buildings E5485, E5487, E5489 (i.e., the "Ghost Town Complex") were surveyed between 1992 and 1994 by using improved instrumentation and a new time-domain electromagnetic instrument designed to detect nonferrous buried metals and to eliminate interference from metals resting on the surface or contained in aboveground structures. Environmental geophysical surveys at the complex were completed during the winter of 1994 by means of the new magnetometer and EM equipment, as well as a bistatic ground-penetrating radar. Equipment used at the latter buildings was also used at Building E3640. Field surveys for Building E3640, described here, were completed between February 1994 and July 1994. 


\section{Contents}

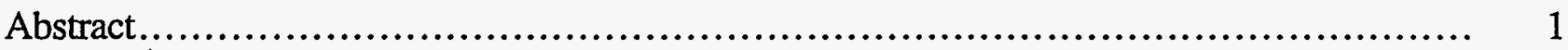

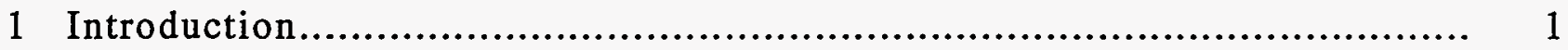

1.1 History of Building E3640 ................................................... 2

1.2 Site Reconnaissance.......................................................... 4

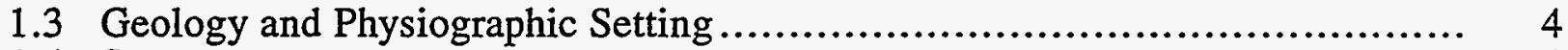

1.4 Surveys........................................................................... 4

1.5 Survey Grid and Locations of Observations ................................. 5

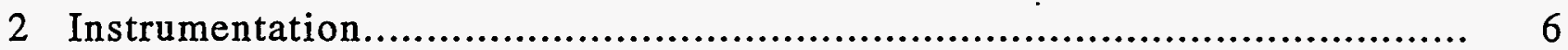

2.1 Magnetic Gradiometer and Cable Locator........................................ 6

2.2 Magnetometer............................................................... 7

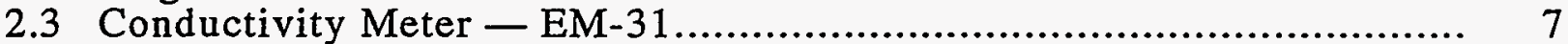

2.4 Time Domain Millivolt Meter — EM-61........................................ 8

2.5 Ground-Penetrating Radar System ............................................ 8

3 Geophysical Measurements and Surveys........................................... 10

3.1 Magnetometer Measurements .................................................... 10

3.2 Horizontal Profiling/Electromagnetic Measurements............................. 18

3.2.1 Conductivity - EM-31 ............................................. 18

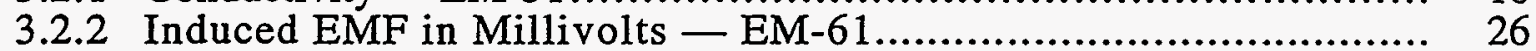

3.3 Ground-Penetrating Radar Measurements..................................... 35

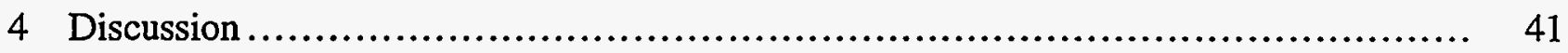

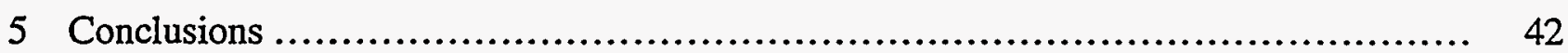

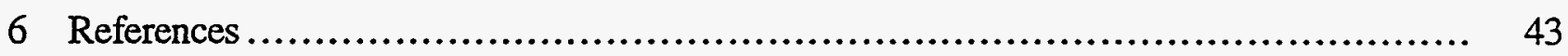

Appendix A: Building E3640 History and Characteristics — from Nemeth 1989..... 45

Appendix B: Ground-Penetrating Radar Line Coordinates for Building E3640........ 53

\section{Table}

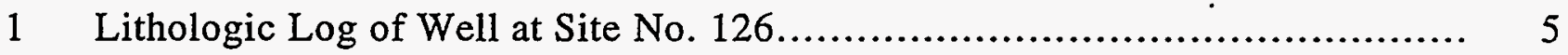

\section{Figures}

1 General Site Map of E3640, Aberdeen Proving Ground, Maryland ................ 2

2 Site Map of the Building E3640 Complex and Areas 1 through 5................. 3 


\section{Figures (Cont.)}

3 Map of the Total Magnetic Field with Sensing Head $1 \mathrm{ft}$ above the Ground....

4 Magnetic Field in Area 1.

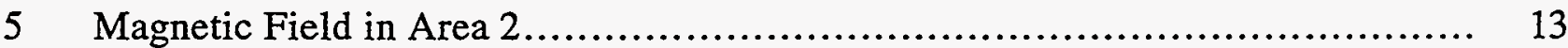

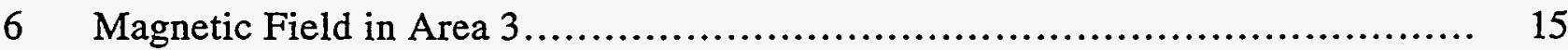

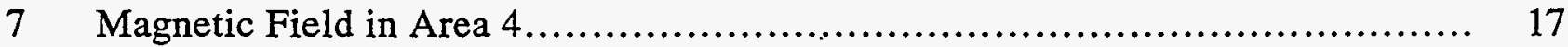

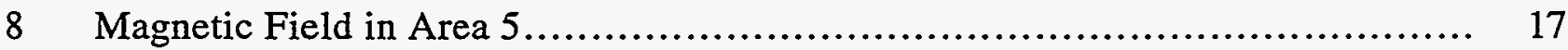

9 Weighted Mean Conductivities of the Upper $18 \mathrm{ft}$ in the Building E3640

Complex Using the EM-31 ........................................................ 19

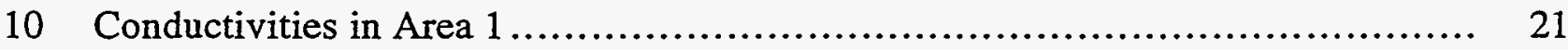

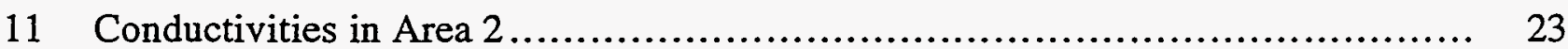

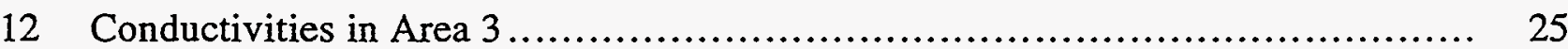

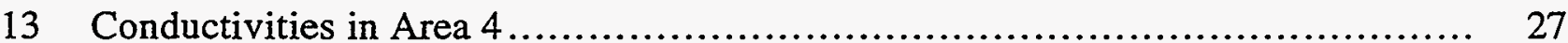

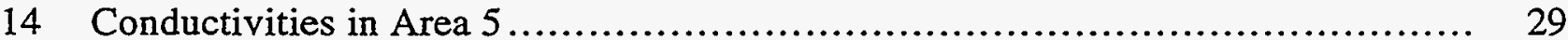

15 Induced EMFs from Buried Metals around Building E3640,

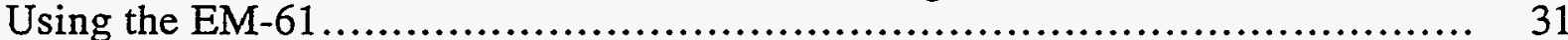

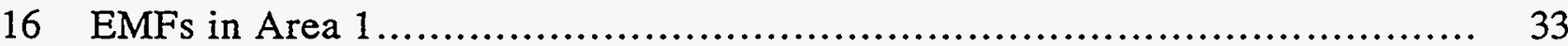

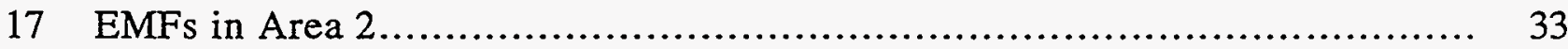

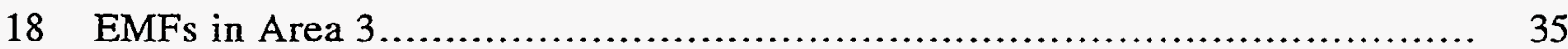

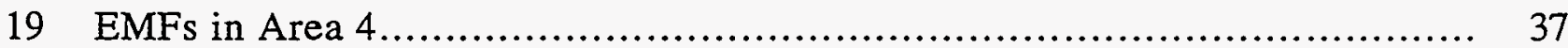

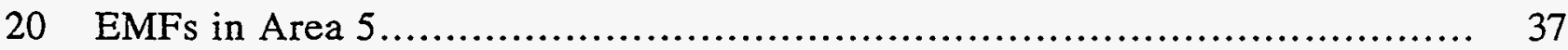

21 Ground-Penetrating Radar Profiles ............................................. 39

22 Underground Utilities in the Building E3640 Complex ......................... 40 


\title{
Interim Progress Report - \\ Environmental Geophysics: \\ Building E3640 Decommissioning, Aberdeen Proving Ground, Maryland
}

by

\author{
L.D. McGinnis, S.F. Miller, H.M. Borden, M.A. Benson, \\ M.D. Thompson, C.A. Padar, and C.R. Daudt
}

\begin{abstract}
Building E3640 is a potentially contaminated site in the Edgewood area of Aberdeen Proving Ground. Noninvasive geophysical survey techniques, including magnetics, EM-31, EM-61, and ground-penetrating radar, were used as part of a sampling and monitoring program prior to decommissioning and dismantling of the building. Complex and large-amplitude anomalies caused by aboveground metal in this area obscure many smaller features produced by subsurface sources. No underground storage tanks were found in the areas surveyed. Major anomalies produced by subsurface sources include the following: EM-61 and EM-31 lineaments caused by a water line extending north from the south fence; a broad positive magnetic anomaly caused by magnetic fill north of the material and drum storage area and northeast of E3640; a 30-ft-wide band of EM-31 anomalies extending from the front gate to the southeast corner of E3640 and a coincident EM-61 anomaly produced by buried utilities; ground-penetrating radar images along three lines extending from a sump at the northeast corner of E3640 to the eastern fence; and EM-61, EM-31, and magnetic anomalies caused by overhead and underground pipes extending south from the north fence. Smaller, unidentified, localized anomalies' observed throughout the survey area are also described in this report.
\end{abstract}

\section{Introduction}

Aberdeen Proving Ground (APG), located in Maryland, is managing a comprehensive Installation Restoration Program involving more than 360 solid waste management units within 13 study areas. The Edgewood area of Aberdeen appears on the National Priorities List under the Comprehensive Environmental Response, Compensation, and Liability Act. APG has entered into an Interagency Agreement with the U.S. Environmental Protection Agency to address the listed areas.

A report by EAI Corporation (1989) included a list of 29 potentially contaminated buildings at APG. The buildings have been abandoned and operations have ceased, but processing 
equipment, sumps, drains, ventilation systems, and underground storage tanks remain. These appurtenances may contain liquid, solid, or vapor contaminants of unknown nature. Sixteen of the buildings contain known contaminants, nine contain unknown contaminants, and four are potentially clean. The EAI report recommended that a sampling and monitoring program be implemented to verify contamination levels in and around each building. Most of the effort thus far has been in the Canal Creek area.

Building E3640 (Figure 1), on the north side of Beach Point, is in the drainage basin of Kings Creek. APG is proceeding with a program to decommission the building, which will prevent the actual or potential release of contaminants into the environment. Argonne National Laboratory (ANL) has been assigned the task of developing a plan and scope of work for the proposed decommissioning. ANL has determined that the first step in this decommissioning process, where technically feasible, should be a noninvasive geophysical survey around building exteriors (see Figure 2 for the general location map of the study area and dimensions of the area surveyed).

\subsection{History of Building E3640}

According to the RCRA Facility Assessment Report, Edgewood Area, Aberdeen Proving Ground, Maryland prepared by Nemeth (1989), Building E3640 is a four-story building constructed in 1951 and 1952 for use as a chemical processing plant. A report on records examined by EAI Corporation (1989) contains minor inconsistencies regarding the dates on which

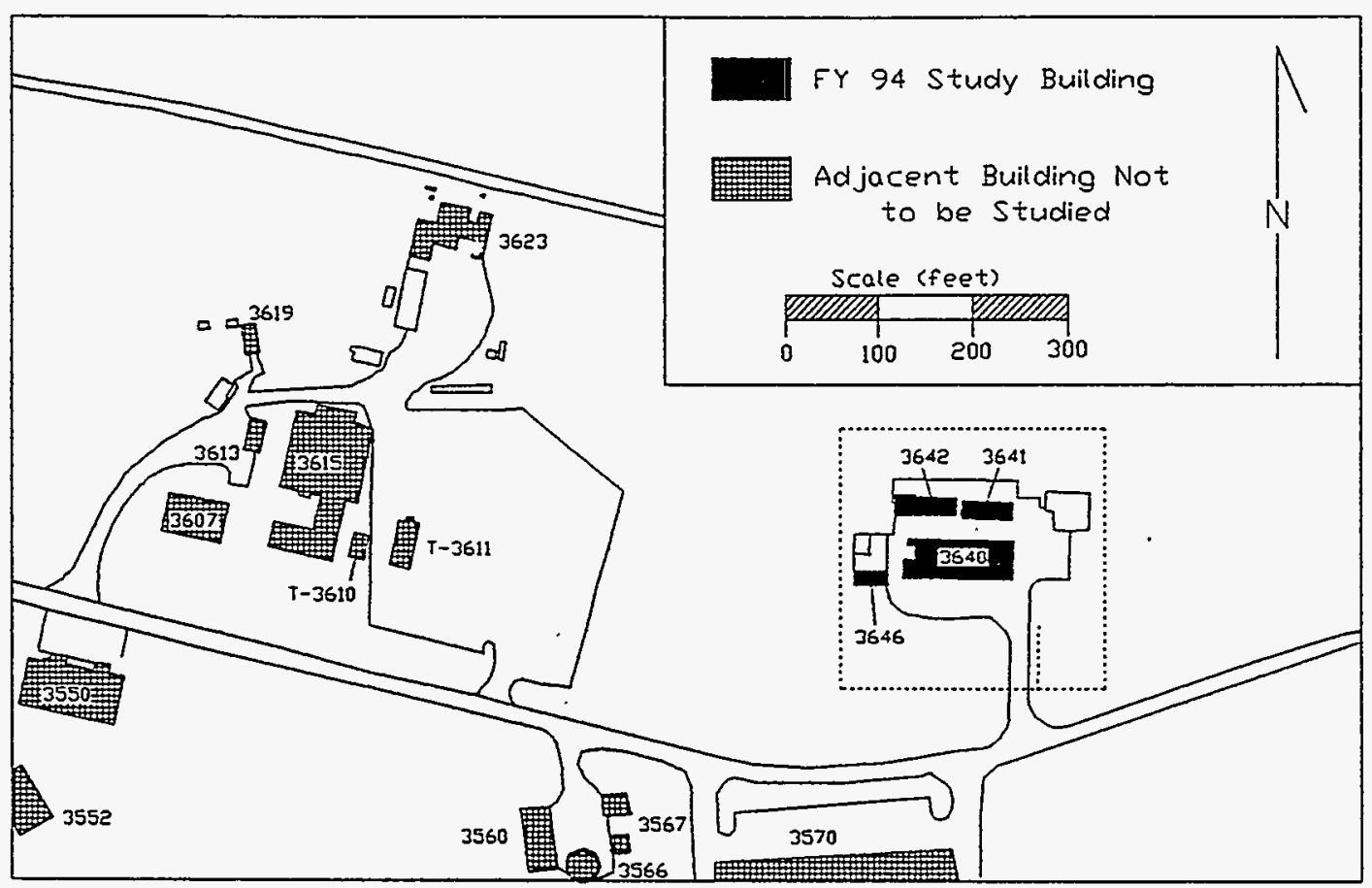

FIGURE 1 General Site Map of E3640, Aberdeen Proving Ground, Maryland 


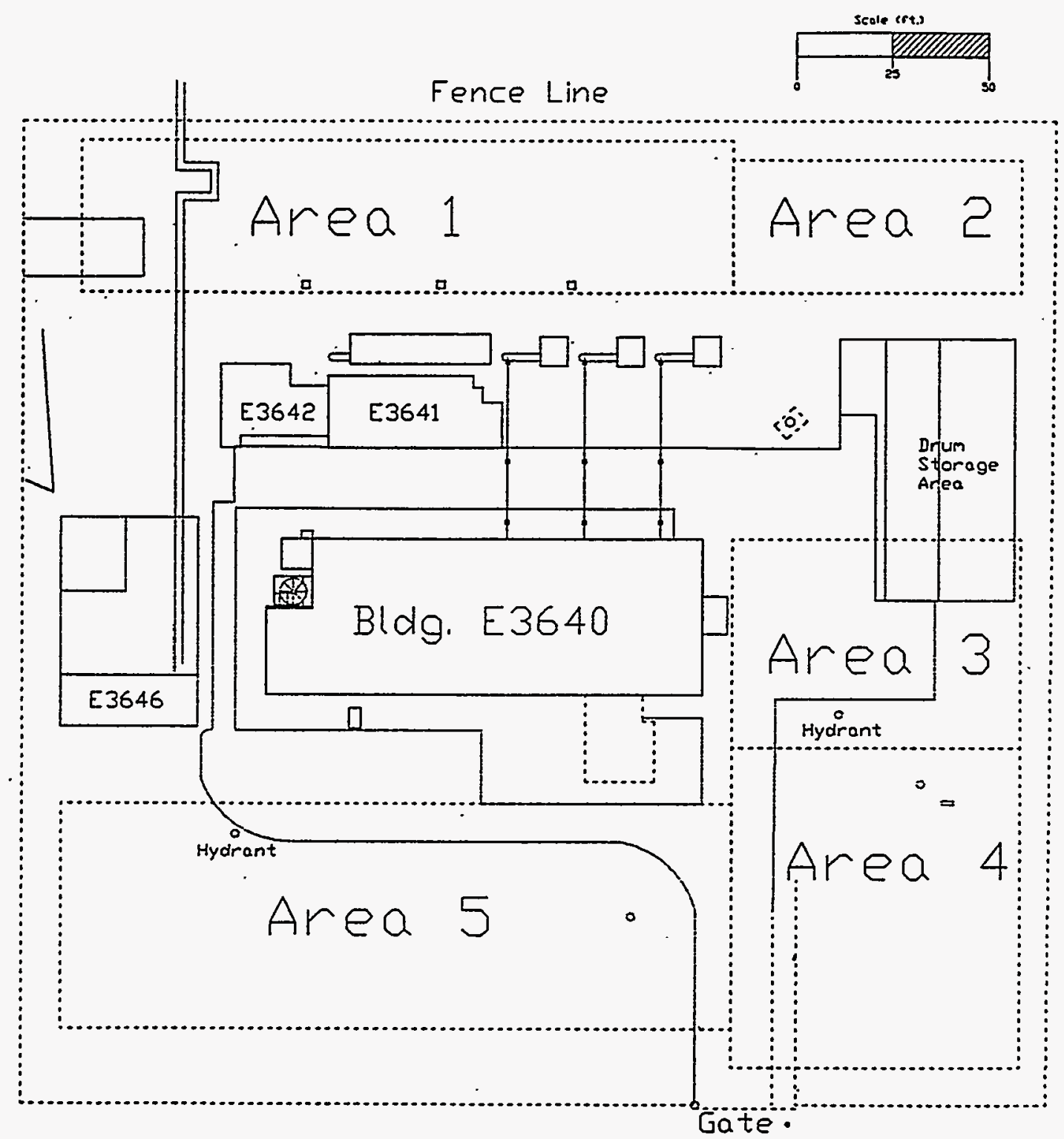

FIGURE 2 Site Map of the Building E3640 Complex and Areas 1 through 5 
building operations began and ended; therefore, Appendix A presents the history and building characteristics quoted directly from Nemeth (1989).

\subsection{Site Reconnaissance}

The geophysical program design for Building E3640 is based upon studies made by ANL personnel in the Edgewood area of APG since 1991 (see ANL Interim Progress Reports listed in Section 6 - References). The initial evaluation was enhanced by a November 1991 site visit and by inspection of aerial photographs.

\subsection{Geology and Physiographic Setting}

The site occupies the topographically low and flat terrain of the Coastal Plain physiographic province in the floodplain and former wetlands bordering Kings Creek, a tributary of Bush River. The Kings Creek area is underlain by alluvial and estuarine sands, silts, and clays. A thin veneer of sediments of the Talbot Formation of Pleistocene age overlies unconsolidated sediments of the Potomac Group of Cretaceous age (Oliveros and Gernhardt 1989). The water table is less than $5 \mathrm{ft}$ below the surface.

Lithologies at the site were determined from the sample study of a well (site no. 126) drilled approximately $400 \mathrm{ft}$ east of Building E3640. The descriptive log, given in Table 1, was part of a hydrogeologic study of the Canal Creek area performed by the U.S. Geological Survey (Oliveros and Gernhardt 1989).

Facies represented at the site include thin beds of varying stratigraphy. Initial construction probably involved considerable amounts of excavation and use of fill material, so most of the shallow sediment at the site has been reworked.

\subsection{Surveys}

Geophysical data were acquired over four days of field operations during the winter of 1993/94. On-site personal computers (both notebook and desktop), interactive software, field equipment (designed specifically for APG building studies), and an all-terrain vehicle were used to expedite data acquisition and processing. Surveys included magnetic gradiometry, total field magnetics, conductivity (EM-31), induced electromagnetic field (EM-61), and ground-penetrating radar (GPR). 
TABLE 1 Lithologic Log of Well at Site No. 126

\begin{tabular}{lrc}
\hline \multicolumn{1}{c}{ Descriptiona } & $\begin{array}{c}\text { Depth } \\
(\mathrm{ft})\end{array}$ & $\begin{array}{c}\text { Thickness } \\
(\mathrm{ft})\end{array}$ \\
\hline Soil - clayey brown, with roots & 0.7 & 0.7 \\
Sand - clayey, dark brown-orange (10YR 4/6), (fU), moist & 3.3 & 2.6 \\
Silt - orange (10YR 4/6) and gray (5Y 6/1) mottled, hard, dry & 4.0 & 0.7 \\
Silt - clayey, green, brown, and orange mottled (fU), with thin sand lenses & 6.1 & 2.1 \\
Sand - white, yellow, and orange (10YR 7/8) mottled, dry & 9.0 & 2.9 \\
Sand - white to pink (mL-mU), orange-streaked, micaeous, increasing & 13.1 & 4.1 \\
wetness with depth & 14.0 & 0.9 \\
Sand - light orange (10YR 7/6) (mL-mU), wet & 17.5 & 3.5 \\
Sand - orange (10YR 6/8) (mL-mU), micaeous, wet & 19.0 & 1.5 \\
No sample & 19.6 & 0.6 \\
Sand - orange (10YR 6/8) (mL), with thin, gray, clayey sand lenses & 20.0 & 0.4 \\
Sand - gray (2.5YR 4/0) (mL), lignitic, clayey sand lenses & 24.0 & 4.0 \\
Sand - clayey, dark gray (2.5YR 3/0), micaeous, lignitic, soft wet & & \\
\hline
\end{tabular}

a Codes enclosed in brackets at selected horizons refer to color designations as specified in the Munsell Soil Color Charts (1975).

Source: Oliveros and Gernhardt (1989).

\subsection{Survey Grid and Locations of Observations}

Prior to geophysical surveying, wooden stakes were placed at the site corners; the southwest corner served as the zero coordinate. Positive coordinates were measured north and east of the zero coordinate. Buildings were oriented with their outside walls aligned approximately north-south and east-west. Geophysical profiles, spaced 5 feet apart, were parallel to the sides of the buildings. 


\section{Instrumentation}

Instruments used to collect geophysical data at the site included the following:

- Magnetic gradiometer and cable locator

- Cesium vapor magnetometer

- Conductivity meter (EM-31)

- Time domain millivolt meter (EM-61)

- SIR-3 ground penetrating radar (GPR)

The following sections describe each of these instruments and the software used to reduce and process the data and produce contour maps.

\subsection{Magnetic Gradiometer and Cable Locator}

The Schonstedt MAC-51B magnetic gradiometer and cable locator is a dual-mode instrument designed to detect shallow buried iron and steel objects and trace underground cables and pipes. The system consists of a transmitter and a dual-function receiver to detect anomalous magnetic gradients.

The MAC-51B is an audio device used only for rapid detection of magnetic materials for further analysis with complementary instrumentation; maps or models are not constructed from observations made with this instrument because it is not a calibrated system and does not have digital data recording. Anomalies are identified by changes in sound amplitude and frequency and are marked on the ground surface prior to initiation of other surveys. If anomalies detected with the MAC-51B cannot be verified with the magnetometer (see Section 2.2), the anomaly is assumed to be insignificant.

Application of the MAC-51B in its receiver mode was the first geophysical operation following establishment of survey limits. The gradiometer allows a qualitative description of the site with $100 \%$ ground coverage; the results obtained with other techniques, although more quantitative, are spatially limited to single-point, survey-grid observations or to continuous readings along spaced profiles. 


\subsection{Magnetometer}

A magnetometer survey was used to identify ferromagnetic objects such as tanks, drums, drain pipes, water lines, and small ferrous objects. The EG\&G Geometrics G-822L cesium vapor magnetometer is a continuously recording total field instrument that allows observations in the single-station, stationary mode, or while walking with the sensing head held at some predetermined height above the ground. For the Building E3640 complex, the sensing head was held approximately $1 \mathrm{ft}$ above the ground surface and measurements were made at a walking pace; data were collected at a rate of 10 readings per second. The average station spacing was $0.5 \mathrm{ft}$, along transects spaced 5 feet apart. The instrument is capable of resolution of anomalies to less than one nanotesla $(1 \mathrm{nT})$.

Because of their dipolar field, magnetic anomalies caused by a source with a simple geometric shape display a characteristic configuration consisting of a positive magnetic peak and at least one negative magnetic trough. If iron-rich waste is buried in the northern hemisphere and becomes magnetized in the earth's field, a large positive anomaly will occur over a symmetrically shaped body with a negative offset to the north. The horizontal distance between the paired peak and trough is proportional to the depth of burial, size, and shape of the source; the amplitude of the anomaly is inversely proportional to the depth of burial. Metallic debris at, or just below, the ground surface produces strong, closely spaced magnetic peaks and troughs separated by high gradient areas.

Data sets from the G-822L, contoured using the SURFER V. 4.0 software developed by Golden Software, Inc. (1991), were used to identify potential sources of contaminants and to distinguish them from background. The SURFER software was incorporated into the field acquisition procedure, so that daily map outputs were available for observation and interpretation. Following processing and gridding, anomalies were enhanced using color-coded software developed by ANL.

\subsection{Conductivity Meter - EM-31}

Mean conductivities were obtained with the Geonics EM-31, an electrical induction meter that measures mean terrain conductivity to depths of approximately $20 \mathrm{ft}$. In electromagnetic profiling, electrical current flow is induced into the ground by a transmitter (induction coil), and a receiver measures the secondary magnetic field caused by the low-intensity "eddy" currents induced in the subsurface. Data were collected at 0.5-s intervals with the EM-31 and were stored on the OMNI 720 data logger, which can log quad-phase electrical conductivity data and in-phase inductive data for metals definition, as well as store survey geometry. Data for this survey were recorded in quad-phase only. Internal software allowed downloading directly into an on-site computer. Conductivity contouring was incorporated into the field acquisition procedure so that daily map outputs were available for observation and interpretation. ANL staff used electromagnetic methods extensively in the Edgewood area at Beach Point, J-Field, and the Pilot Plant. 


\subsection{Time Domain Millivolt Meter - EM-61}

Field data (in millivolts [mV]) were obtained with an EM-61, a portable, time-domain, electrical induction instrument that transmits an electrical pulse into the ground and measures secondary electromagnetic fields (EMFs) caused by metallic objects beneath the instrument. As a consequence of its coil arrangement, the instrument is relatively insensitive to surface interference and is more sensitive to deeply buried metallic targets. Data are recorded on three channels, including a response from an upper coil ( $\mathrm{CH} 1)$, lower coil (CH2), and coil difference ( $\mathrm{CH} 3)$.

The equation for the difference channel is $\mathrm{CH} 3=\mathrm{k} \times \mathrm{CH} 1-\mathrm{CH} 2$, where $\mathrm{k}$ is a multiplier in the software. Because of its spatial positioning, the lower coil responds to signals from all depths within the instrument range. For example, an anomaly of $2 \mathrm{mV}$ from a 55-gal metal drum buried at a depth of about $9 \mathrm{ft}$ would be detected by the lower coil (Geonics Limited 1994). Data recorded on the coil difference channel (CH3) are less sensitive to surficial debris. Negative values on the difference channel are often associated with metallic objects located above the surface (e.g., overhead steam pipes). Contouring of data (in $\mathrm{mV}$ ) was incorporated into the field acquisition procedure so that daily map outputs were available for observation and interpretation.

Data were collected at a rate of three readings per second and stored on the OMNI 720 data logger. Internal software allowed downloading of the data directly into an on-site computer.

\subsection{Ground-Penetrating Radar System}

Ground-penetrating radar (GPR) surveying was accomplished using a Geophysical Survey Systems, Inc. (GSSI), model SIR-3 with a model 38 video display unit that was connected by a 300-ft cable to a variable-frequency transceiver (GSSI 1987). The SIR-3 was used in both the bistatic and monostatic antenna configurations with 300-megahertz $(\mathrm{MHz})$-frequency antennas. Data were recorded on a digital auto tape through the model 38 system, which was downloaded to a personal computer. The control unit/video display was located in the transport vehicle. An IBM-compatible processing computer was set up in a field office so that radar profiles could be downloaded, data tape quality checked, and preliminary data processing performed on the profiles. Radan III computer software written by GSSI was used for processing the GPR data.

Wave-velocity characteristics of near-surface materials were derived from the known positions of buried objects. Internal calibration was performed at least twice each day to ensure that the graphic record of the range setting was consistent. Studies conducted during the 1991 field season indicated wave velocities of 6-7 nanoseconds per foot (ns/ft) for near-surface sediment; however, conditions vary with the heterogeneity of the subsurface.

Ground-penetrating radar is the best method available to determine the depth and geometry of objects buried near the surface. The weakness of the method is its limited depth of exploration, caused by wave-propagating constraints imposed by the electrical properties of soils. The 
maximum depth of penetration with GPR at Building E3640 was approximately $10 \mathrm{ft}$ below the ground surface. Depths are calculated from known travel times through materials normally found at Aberdeen. 


\section{Geophysical Measurements and Surveys}

\subsection{Magnetometer Measurements}

Figure 3 provides a map of the total magnetic field and data points in the E3640 complex. Buildings and other aboveground hardware produced large-amplitude anomalies that obscure anomalies caused by most subsurface objects of interest. In order to enhance small anomalies produced by subsurface sources, Figure 3 is divided into five small areas where surficial effects are not as dominant. These areas (1 through 5) are shown in Figure 2; "blow-ups" are provided in Figures 4, 5, 6, 7, and 8. Data points are located along transects spaced $5 \mathrm{ft}$ apart.

\section{Area 1}

Magnetic Area 1, shown in Figure 4, contains one anomalous zone in the western quarter of the map. Anomalies are concentrated beneath an overhead pipe in this area. Sources probably include underground and overhead ferrous metals.

A cluster of positive and negative anomalies is centered at $52 \mathrm{E}, 245 \mathrm{~N}$ in the western quarter of Figure 4. These anomalies, ranging from 10,000 $\mathrm{nT}$ above background to $10,000 \mathrm{nT}$ below background, are caused by overhead pipes and fencing.

Bands of anomalies along the north margin of the area are caused by the security fence. Anomalies along the south margin are produced by buildings; one point source anomaly located at $182 \mathrm{E}, 239 \mathrm{~N}$ has an unknown origin.

\section{Area 2}

Magnetic Area 2, shown in Figure 5, is dominated by a broad, low-amplitude positive anomaly (200-300 nT) north of the drum storage area. The anomaly is not caused by aboveground objects or naturally occurring subsurface geological materials. On the basis of the site history and the anomaly's shape and amplitude, it may be caused by amphibolitic fill material. No other buried, ferrous metal objects were observed in this area.

\section{Area 3}

Magnetic Area 3, shown in Figure 6, contains a large building-induced minimum to the west, with an extension centered at $222 \mathrm{E}, 114 \mathrm{~N}$. The extension is caused by readings taken near a hydrant (see Figure 2). The positive anomaly normally associated with a hydrant is not evident on Figure 6 because the sensing head was not positioned over the hydrant; only the secondary field was mapped. A low-amplitude magnetic positive reaching approximately $800 \mathrm{nT}$ above 


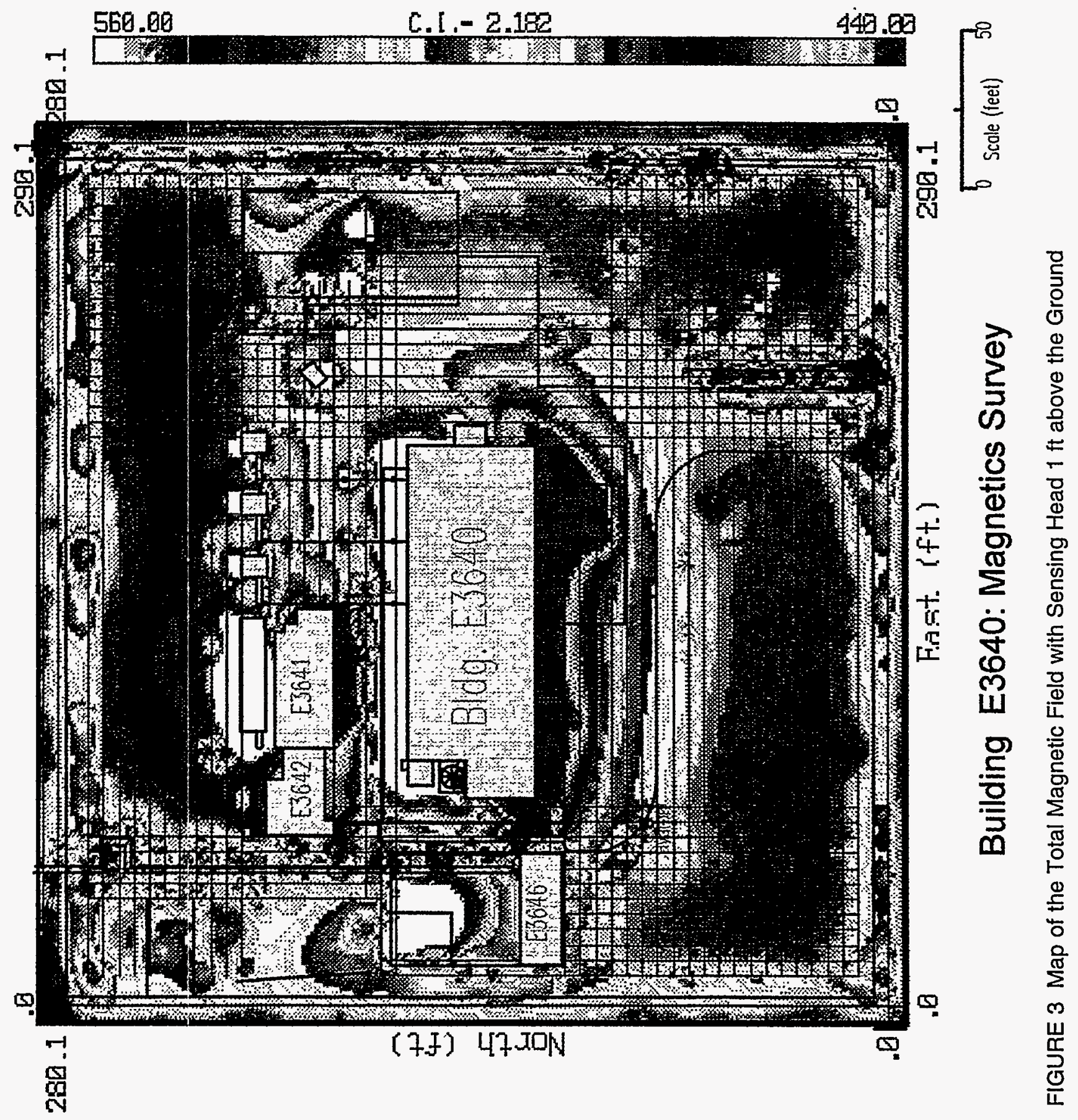




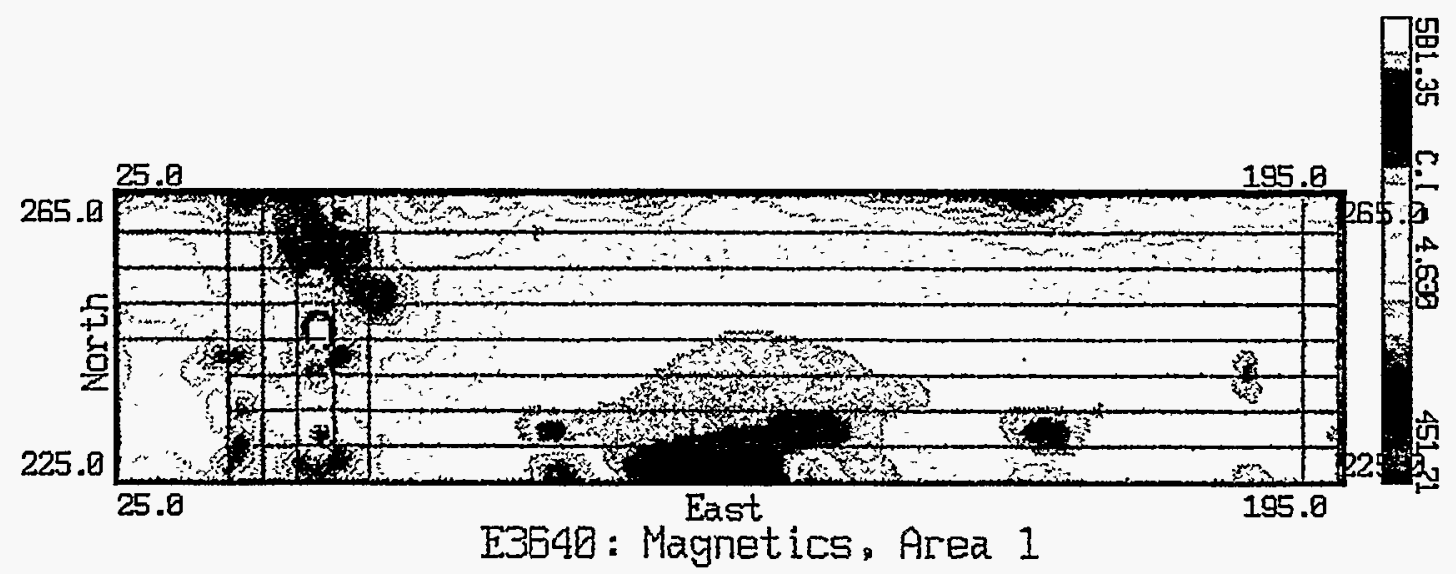

FIGURE 4 Magnetic Field in Area 1

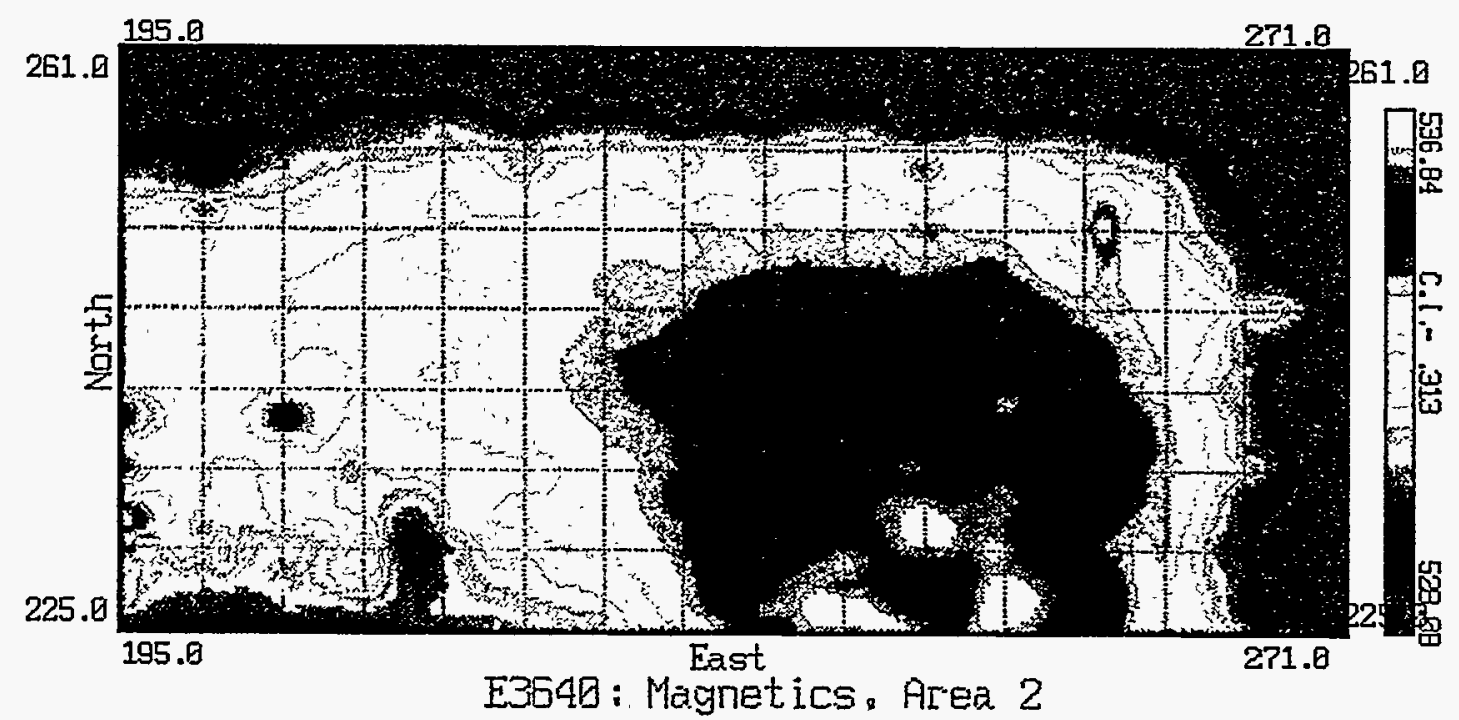

FIGURE 5 Magnetic Field in Area 2

background trends north to south in the eastern third of Area 3. This anomaly is probably caused by magnetic gravel fill like that present in Area 2 . No other anomalies of significance were observed in Area 3.

\section{Area 4}

Magnetic Area 4, shown in Figure 7, contains a number of positive and negative anomalies produced by aboveground objects such as utility poles, guy wires, and reinforcement steel in concrete (e.g., a positive and negative pair at 244E, 95N [positive] and 251E, 90N [negative]. A broad, positive anomaly, with an amplitude of several hundred $\mathrm{nT}$, oriented north to south in the eastern half of the figure is produced by magnetic fill material. 


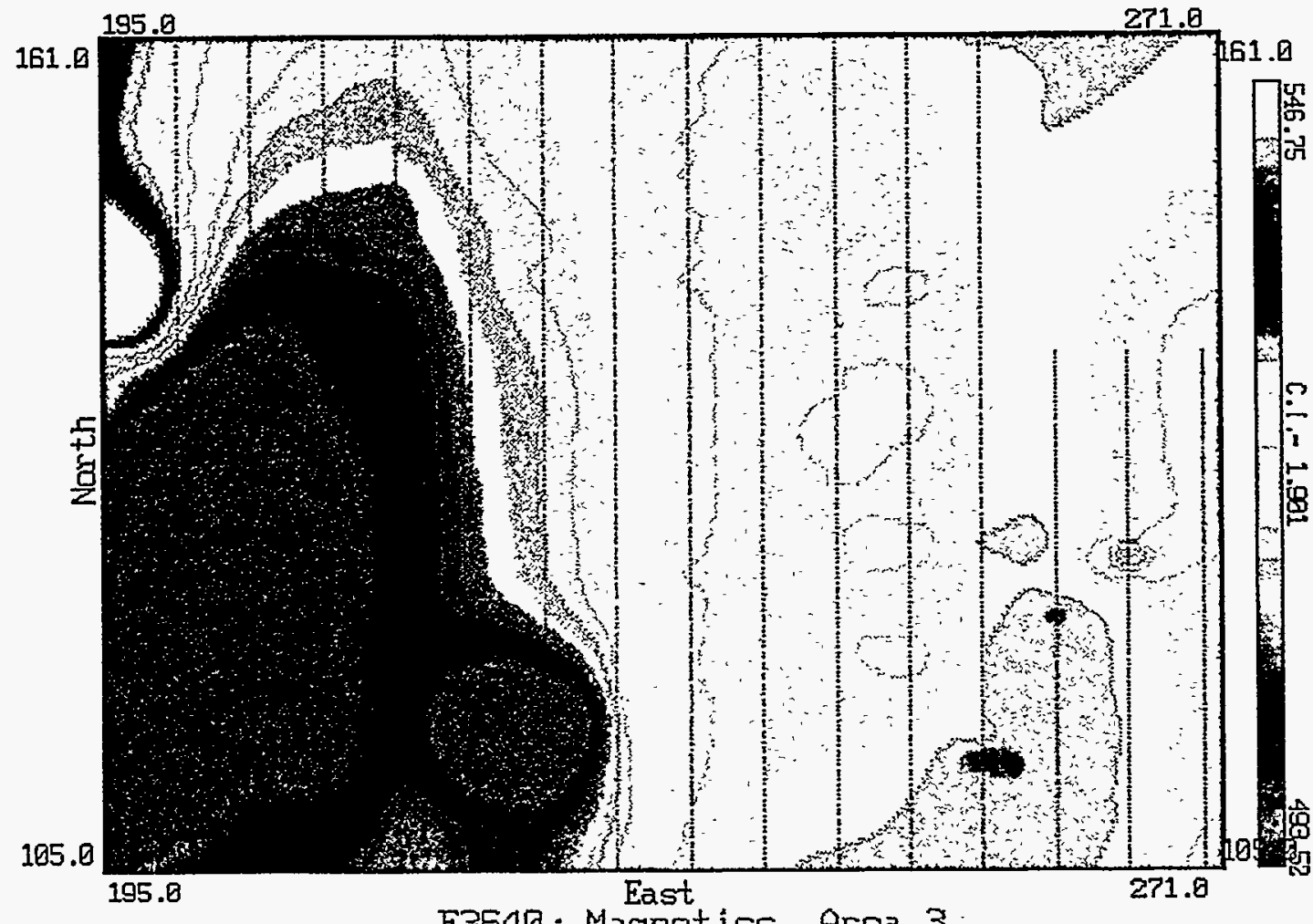

E3640: Magnetics. Area 3

FIGURE 6 Magnetic Field in Area 3

The following unexplained magnetic anomalies were observed in Area 4: one single anomaly at $230 \mathrm{E}, 62 \mathrm{~N}$ (amplitude of 5,000 nT); a cluster of three high-amplitude positive anomalies and a negative pair, centered east of the main gate at 235E, $45 \mathrm{~N}$ (amplitudes of 3,000 to $8,000 \mathrm{nT}$ ); and four small, single-source positive anomalies (amplitudes of 300 to $500 \mathrm{nT}$ ) at $270 \mathrm{E}, 62 \mathrm{~N} ; 260 \mathrm{E}, 49 \mathrm{~N} ; 270 \mathrm{E}, 45 \mathrm{~N}$; and $224 \mathrm{E}, 24 \mathrm{~N}$.

\section{Area 5}

Magnetic Area 5, shown in Figure 8, contains several anomalies caused by aboveground features. These include a large positive $2,000-n \mathrm{~T}$ anomaly around a telephone pole at $168 \mathrm{E}, 60 \mathrm{~N}$; a 900-nT anomaly at a sign post; and a complex of positive and negative anomalies adjacent to a hydrant at $60 \mathrm{E}, 80 \mathrm{~N}$.

The following unexplained anomalies caused by subsurface sources were also observed in Area 5: $1,000-\mathrm{nT}$ positive anomaly point source at $130 \mathrm{E}, 50 \mathrm{~N} ; 300-\mathrm{nT}$ positive anomaly point source at $152 \mathrm{E}, 40 \mathrm{~N} ; 1,500-\mathrm{nT}$ positive anomaly at $158 \mathrm{E}, 25 \mathrm{~N}$; and a broad $500-\mathrm{nT}$ anomaly at $54 \mathrm{E}, 30 \mathrm{~N}$. 


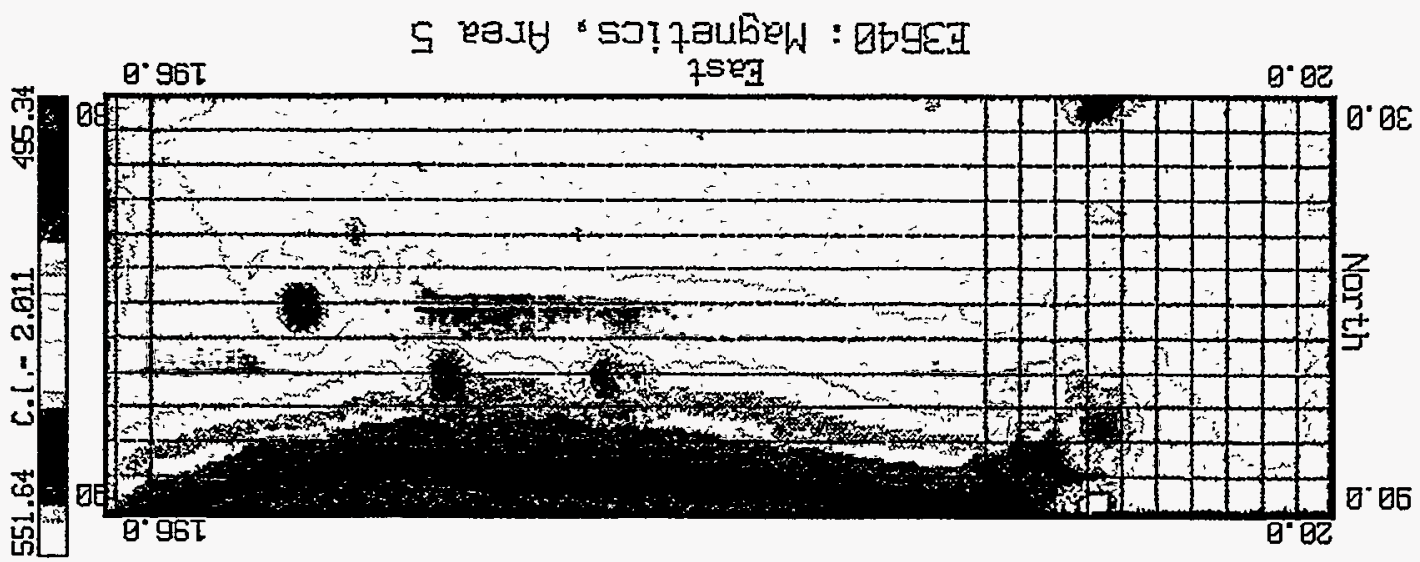

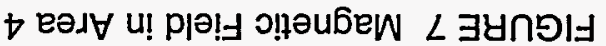

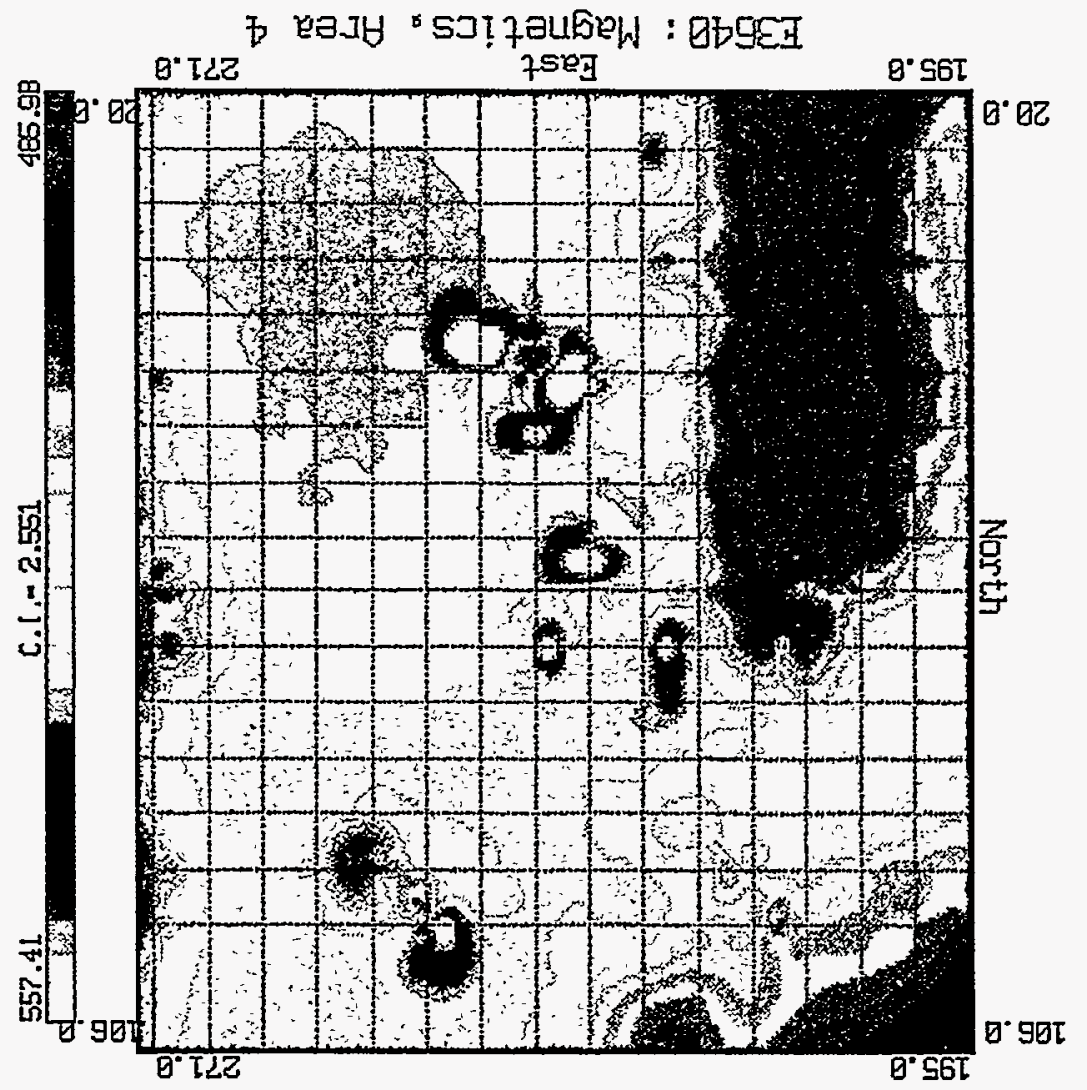


Because of the proximity of this site to wetlands bordering Kings Creek, it is likely that several feet of fill was required to raise the grade of the surface on which the buildings and entrance road were constructed. Broad positive anomalies in Areas 2, 3, 4, and 5 may represent fill material, a good part of which consists of amphibolite.

\subsection{Horizontal Profiling/Electromagnetic Measurements}

\subsubsection{Conductivity - EM-31}

Horizontal profiling with the EM-31 provides a map of mean conductivity from the surface to a depth of $18 \mathrm{ft}$ around the Building E3640 complex (Figure 9). EM-31 data were acquired at a 0.5 -s sampling rate along the same transects surveyed with the magnetometer. Some field distortion was observed near the buildings; however, at least three prominent, linear anomalies are associated with surface and subsurface sources with anthropogenic origins. These anomolies are described by area (from north to south) below.

\section{Area 1}

Conductivity Area 1, shown in Figure 10, contains a north-south negative lineament of 5 millisiemens/meter $(\mathrm{mS} / \mathrm{m})$ flanked by small positive anomalies south of $54 \mathrm{E}, 260 \mathrm{~N}$ and extending southward from the north fence to $215 \mathrm{~N}$. This feature is caused by overhead steam pipes and associated hardware. Two additional north-south negative lineaments extending south from the north fenceline and located east of the first anomaly are unexplained. Both are smaller in amplitude and length than the first anomaly.

\section{Area 2}

Other than anomalies caused by aboveground features, such as fencing on the north and the drum storage area on the south, no lineaments or special conductivity features were observed in Area 2 (Figure 11).

\section{Area 3}

A large positive anomaly in the southwest corner of Area 3 (Figure 12) extends southward into Area 4 . The anomaly is caused by a hydrant and associated underground water line, overhead pipes, and road fill. The anomaly is best represented on Figure 9, where its entire length (from the front gate entrance to the southeast corner of Building E3640) is marked by a curving, 30 -ft-wide band of short wavelength, high-amplitude anomalies. 


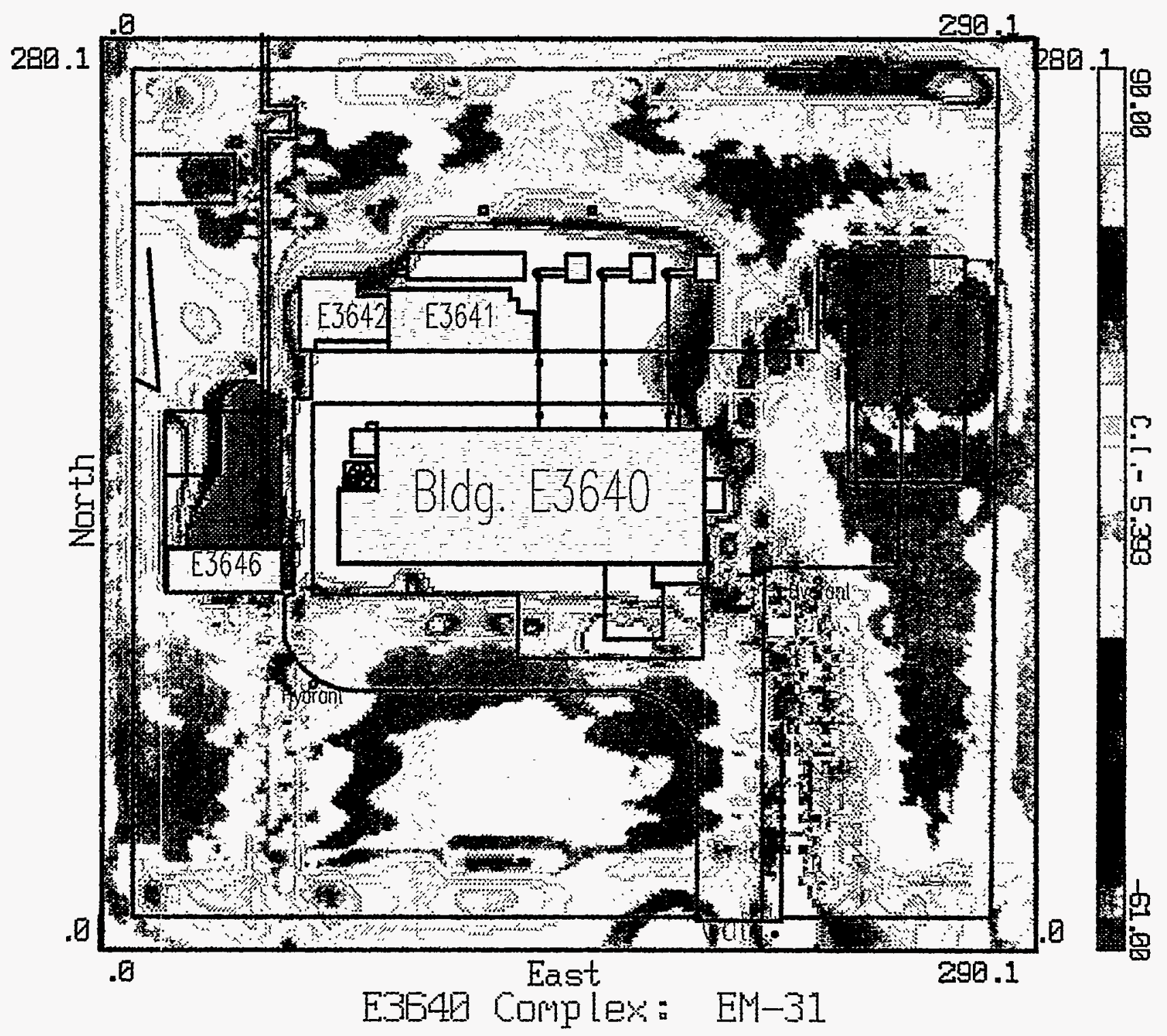

FIGURE 9 Weighted Mean Conductivities of the Upper $18 \mathrm{ft}$ in the Building E3640 Complex Using the EM-31 


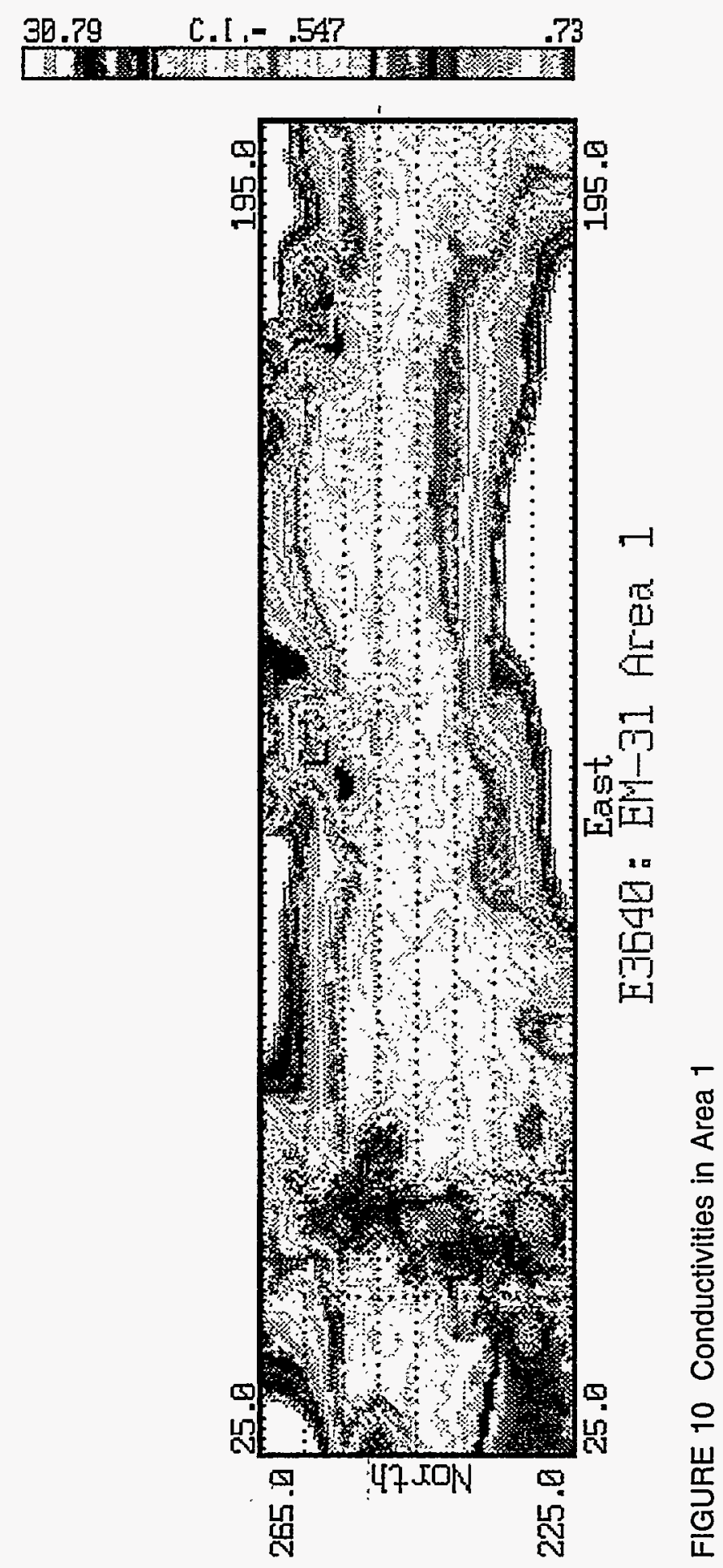




\section{$25.26 \quad 6.1 .227 \quad 12.76$}
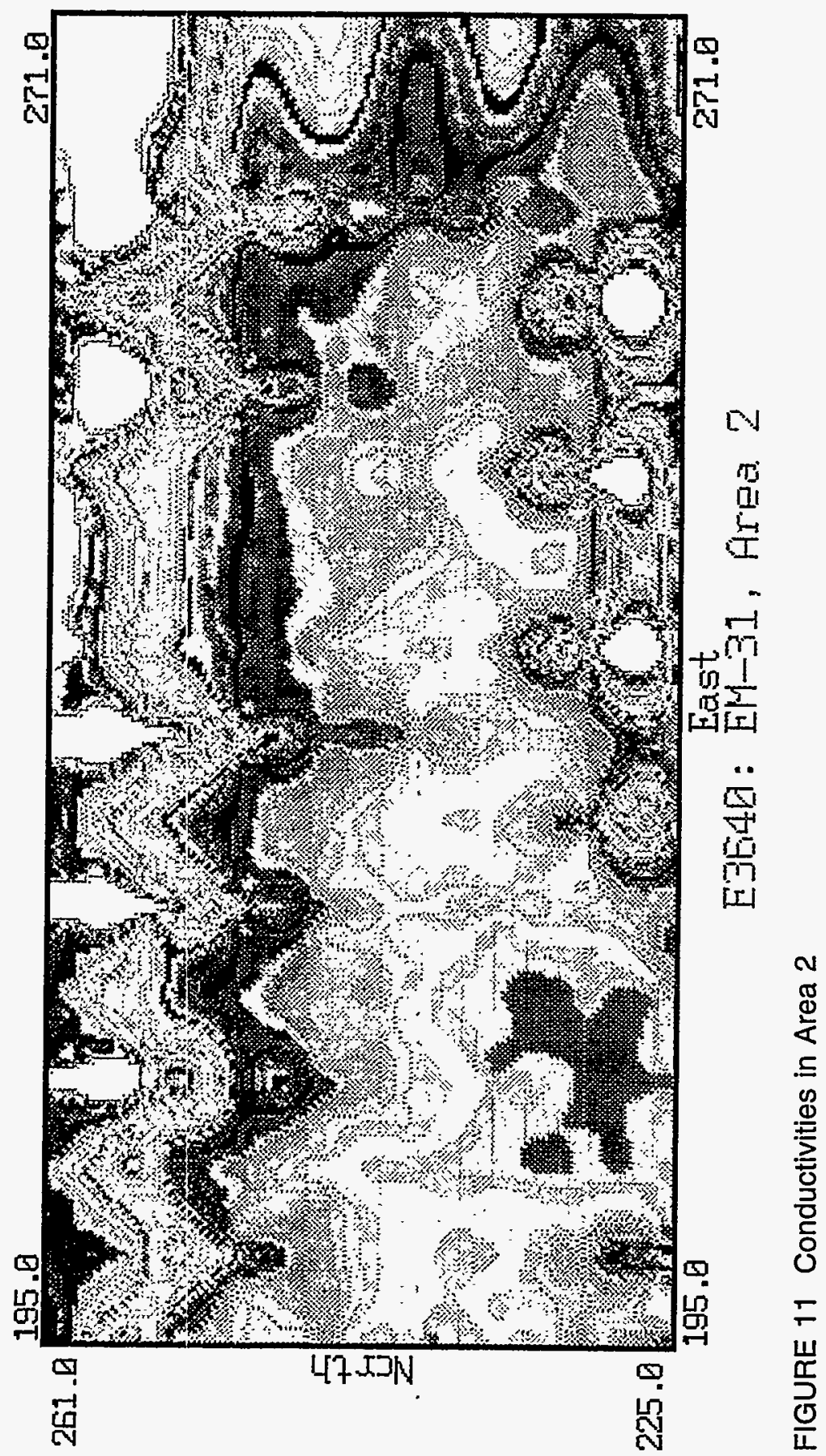
相.91

C. $1 .-1.018$ $-15.8 \mathrm{~B}$

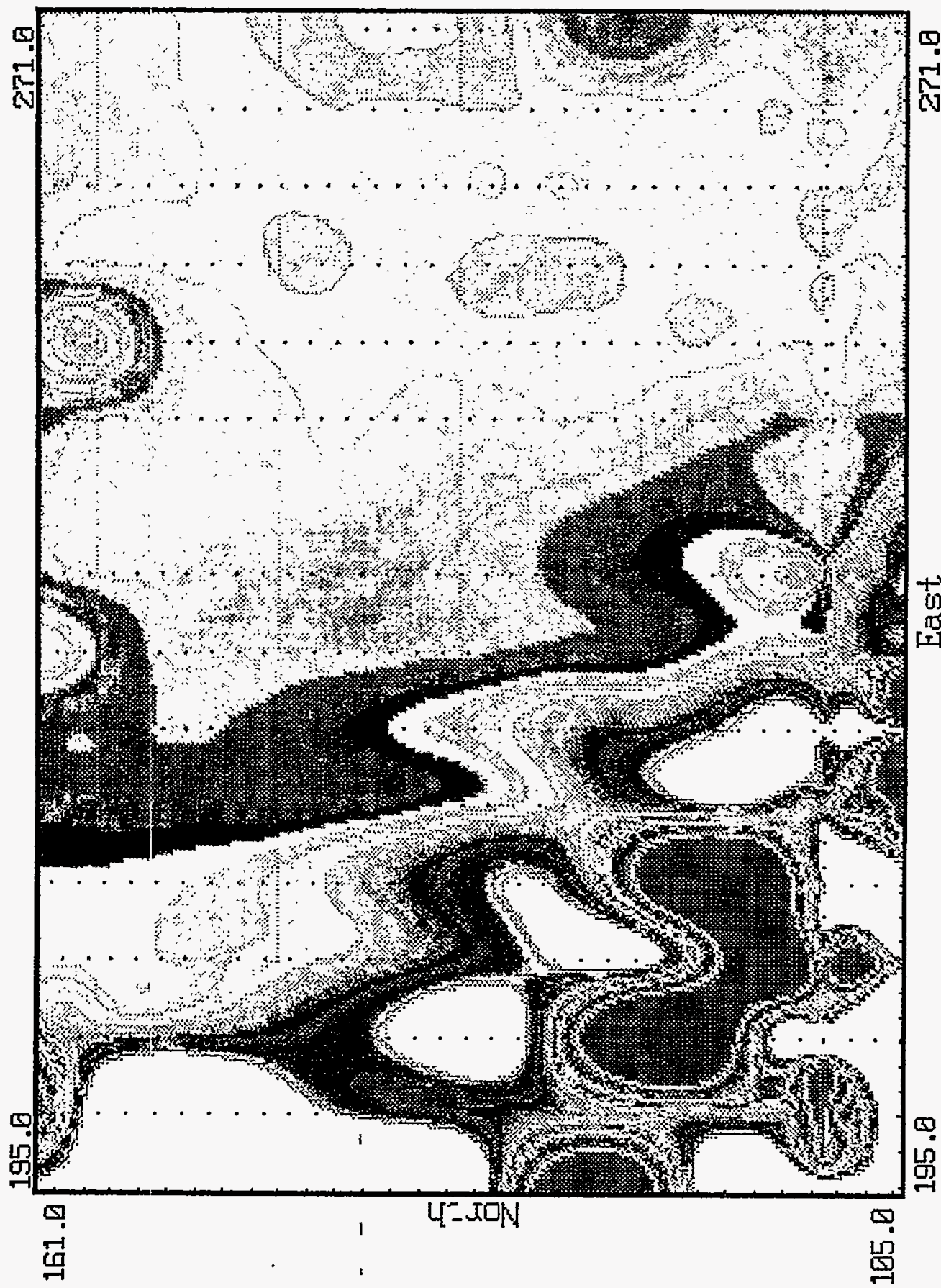

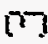

I

몬

$+9$

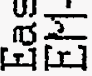

覃

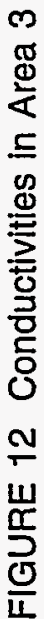




\section{Area 4}

The anomaly complex described in Area 3 extends from the north to the south border of Area 4 (Figure 13) as a 30-ft-wide band of positive and negative lineaments. The observed anomalies are obviously associated with the entry road, overhead pipes, and security fence.

\section{Area 5}

A prominent positive/negative lineament oriented north-south is the only notable feature in Area 5 (Figure 14). This lineament is caused by a buried water line extending from Beach Point Road to a hydrant at the north end of the lineament. No other features of note are visible on the map.

\subsubsection{Induced EMF in Millivolts - EM-61}

Figure 15 presents a map constructed from EM-61 CH2 data (coil \#2 - the lower coil that responds to all metals from the surface to approximately $9 \mathrm{ft}$ ). Anomalies and their sources are described in the following paragraphs, by area.

\section{Area 1}

A band of positive anomalies, centered at 57E, $245 \mathrm{~N}$, was observed beneath a north-southtrending steam pipe (Figure 16). The anomalies appear, on first inspection, to be caused by overhead piping; however, most of the anomaly band on the "difference" channel is positive. Therefore, the anomalies must be caused by a subsurface source, probably a drain line into the northern wetland. A band of anomalies along the southern margin of the area is caused by aboveground supports for guy wires and by other utilities associated with Buildings E3642 and E3641. Subsurface sources are indicated by the following anomalies: a $9.3-\mathrm{mV}$ anomoly at $86 \mathrm{E}$, $260 \mathrm{~N}$; an $11-\mathrm{mV}$ anomaly at $99 \mathrm{E}, 258 \mathrm{~N}$; a $6-\mathrm{mV}$ anomaly at $90 \mathrm{E}, 249 \mathrm{~N}$; a broad anomaly extending across two traverse lines at $182 \mathrm{E}, 258 \mathrm{~N}$; and several mixed metal sources measuring $33 \mathrm{mV}$ and centered at $187 \mathrm{E}, 237 \mathrm{~N}$.

\section{Area 2}

Area 2 is free of buried metal except for two sources along the southern border (Figure 17). These features, one at 235E, 228N and the other at 250E, 228N, are not identified. The amplitude of the anomalies indicates that they represent large objects (5-10 ft across), possibly buried tanks. 


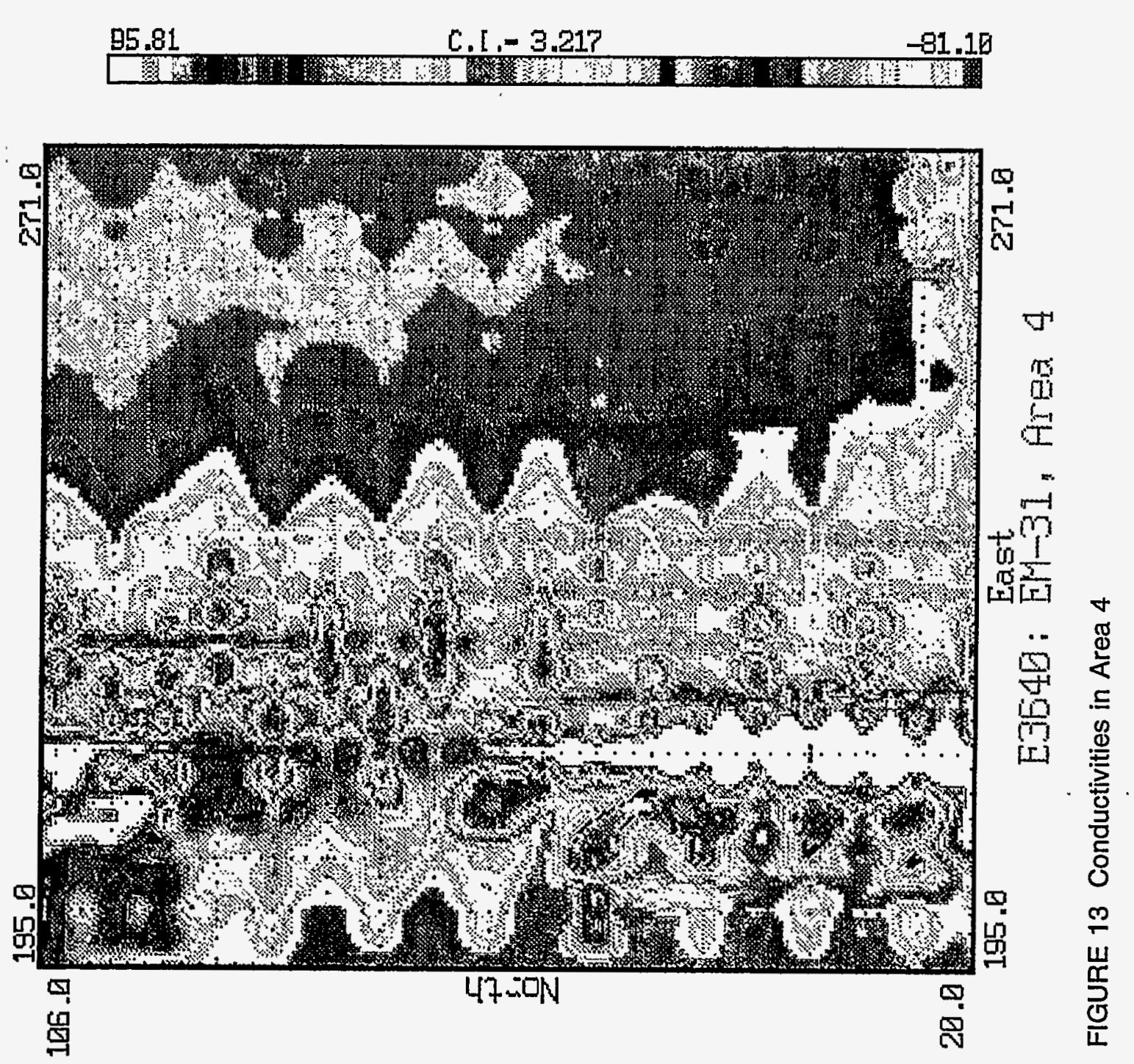



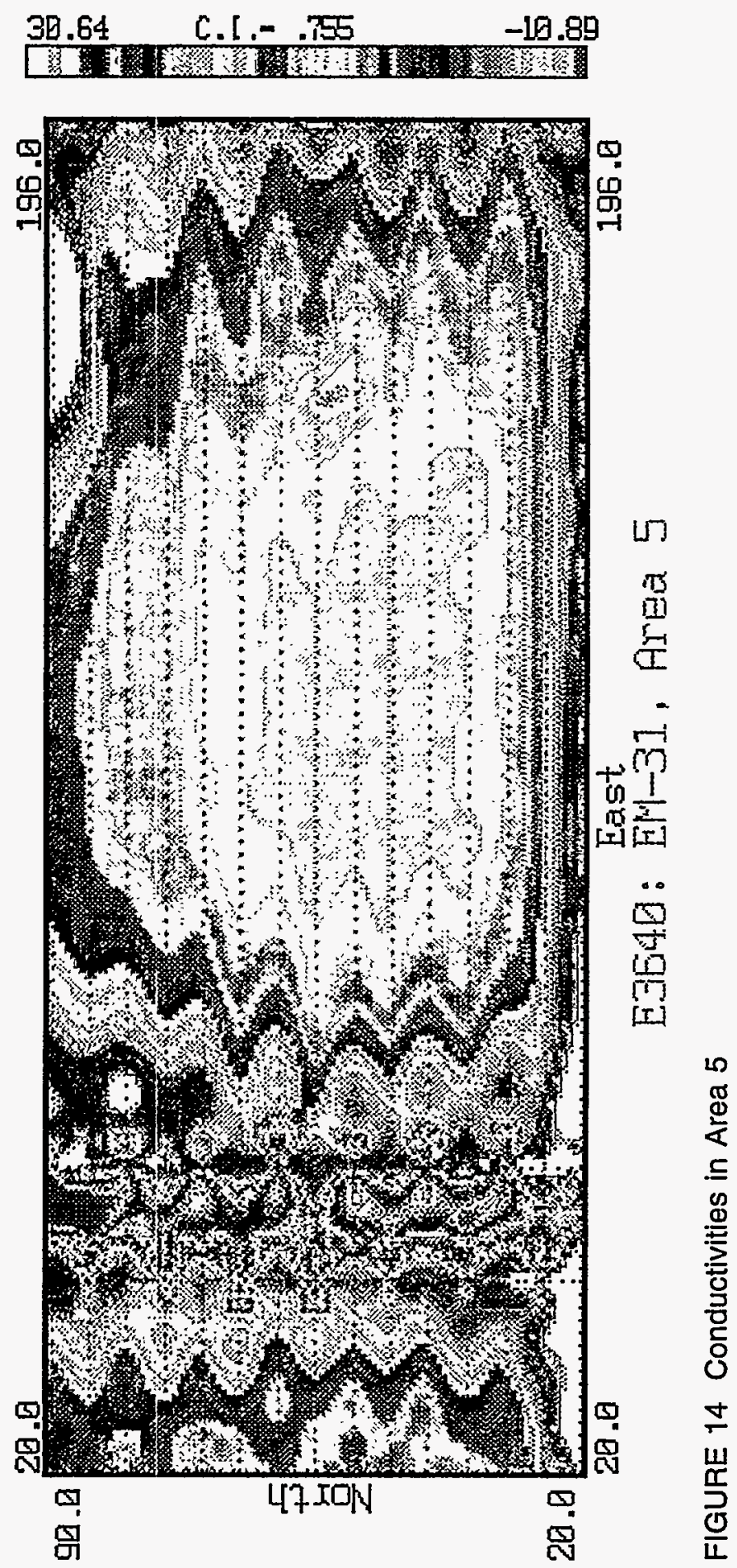


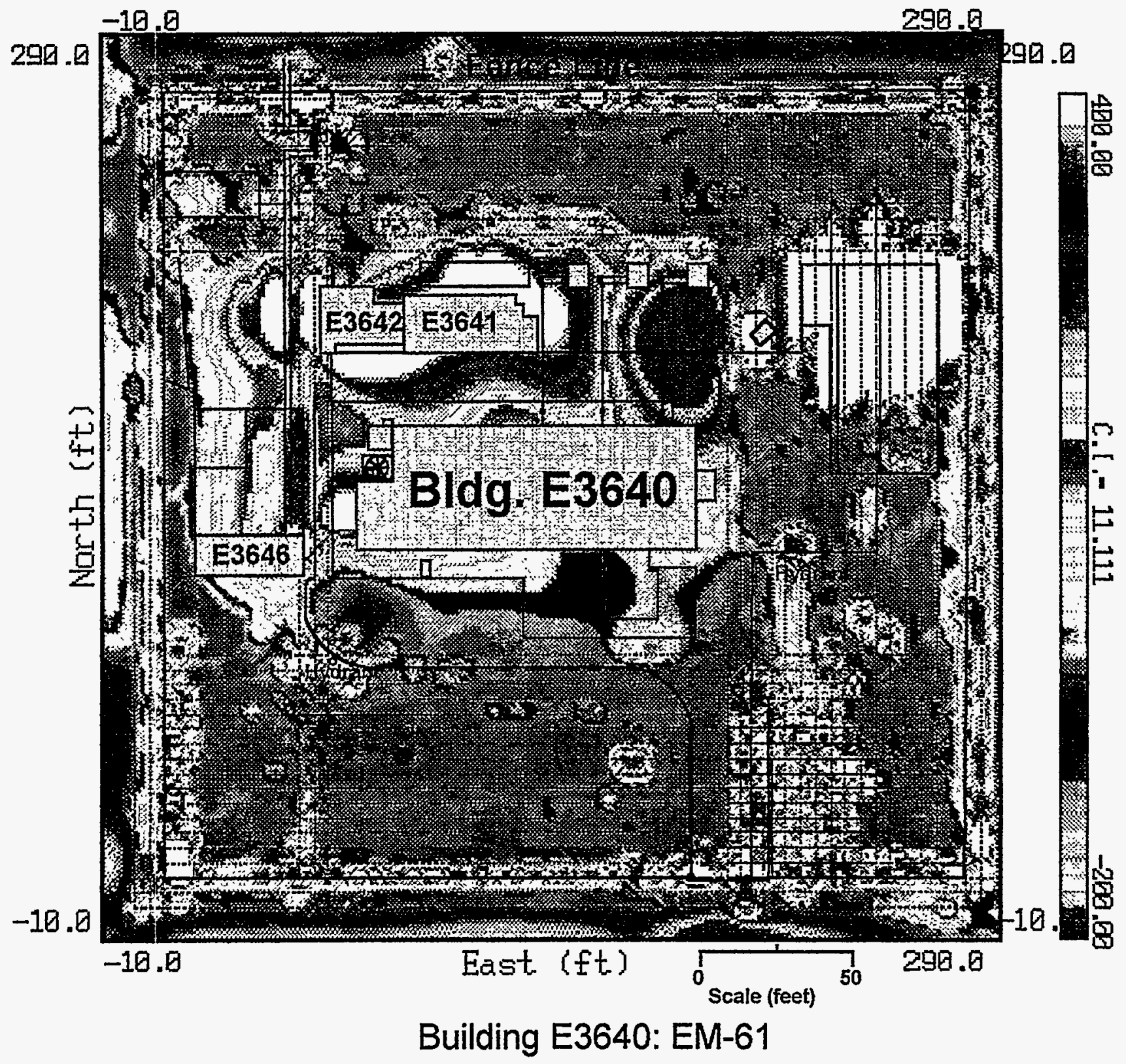

FIGURE 15 Induced EMFs from Buried Metals around Building E3640, Using the EM-61 (Coil \#2) 


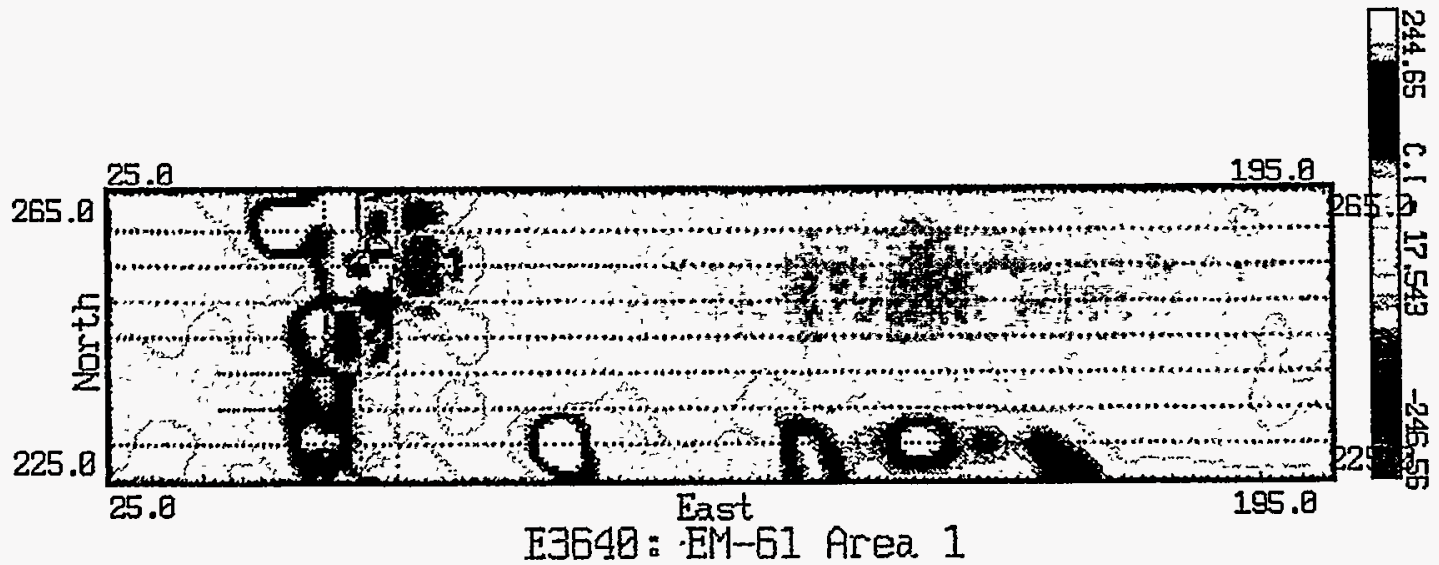

FIGURE 16 EMFs in Area 1

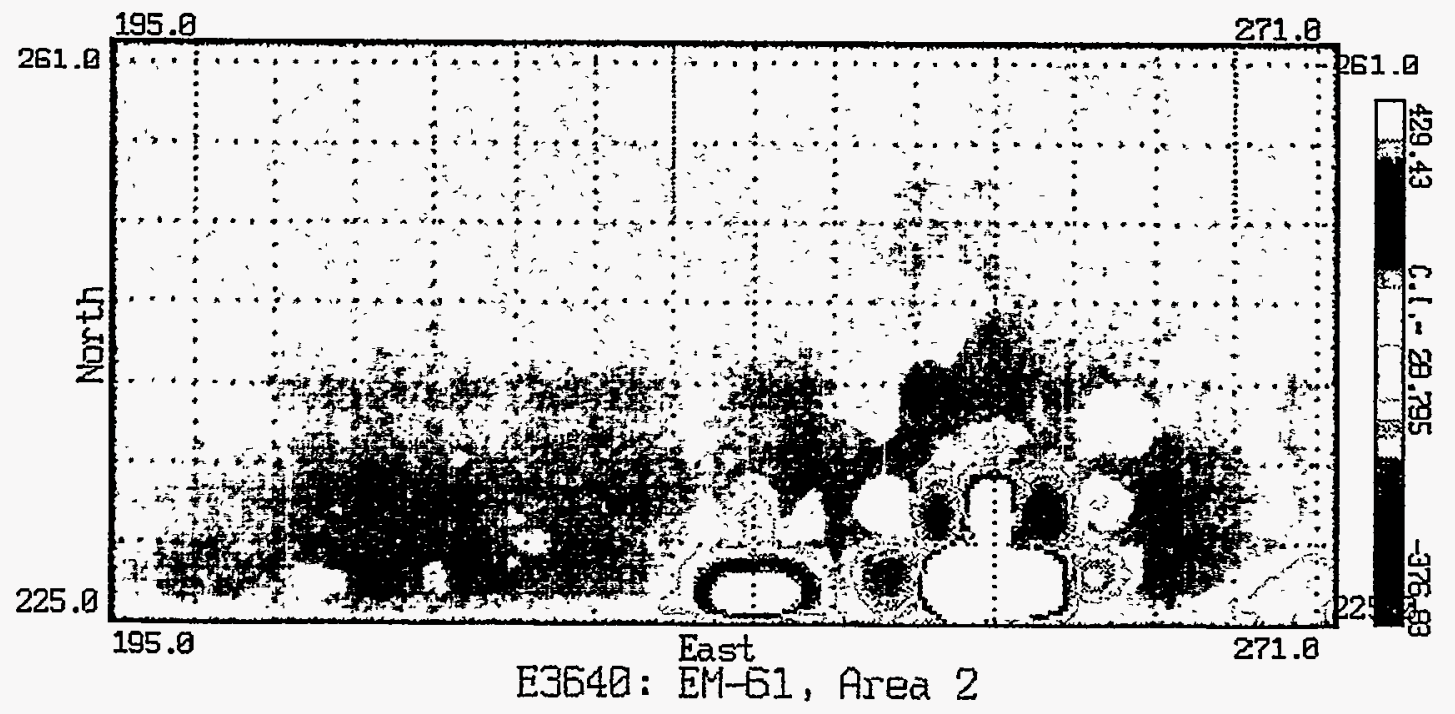

FIGURE 17 EMFs in Area 2 


\section{Area 3}

The southwest quadrant of Area 3 contains a prominent anomaly produced by a fire hydrant and its associated underground water lines (Figure 18). The primary anomaly is centered at 221E, $117 \mathrm{~N}$, with two smaller positive extensions, one to the northwest and a second extending due south from the hydrant.

Two positive anomalies located in the northeast quarter of Area 3 (Figure 18) are unrelated to the hydrant; their source is uncertain.

\section{Area 4}

A positive anomaly lineament extending southward from the northern border of Area 4 (Figure 19) is a continuation of the hydrant and water line anomolies defined in Area 3. The water line anomaly is obscured where it merges with a 50-ft-wide band of anomalies extending north from the south gate. An anomaly trending northwest to southeast, consisting of two circular positives, is caused by metals associated with reinforcement in supports for a pole and guy wires. The positive anomalies are centered at $245 \mathrm{E}, 98 \mathrm{~N}$ and $255 \mathrm{E}, 91 \mathrm{~N}$. Two unidentified sources producing positive anomalies are centered at $240 \mathrm{E}, 46 \mathrm{~N}$ and $248 \mathrm{E}, 39 \mathrm{~N}$. These anomalies lie on the eastern margin of the wide band of high-frequency anomalies produced by the fill and utility lines.

\section{Area 5}

Several metal anomalies appearing on Figure 20 are produced by underground and surface sources. These include the following:

- A large positive anomaly centered at $168 \mathrm{E}, 48 \mathrm{~N}$ caused by a sign and post,

- A series of anomalies south of 59E, $81 \mathrm{~N}$ extending to the south fence and caused by an underground water line and hydrant near the southwest corner of E3640,

- An east-west-trending positive lineament at $65 \mathrm{~N}$, between $117 \mathrm{E}$ and $160 \mathrm{E}$,

- A point source anomaly at $159 \mathrm{E}, 36 \mathrm{~N}$,

- Very low-amplitude point source anomalies at 166E, 26N; 139E, 32N; 90E, $50 \mathrm{~N} ; 72 \mathrm{E}, 50 \mathrm{~N} ; 46 \mathrm{E}, 47 \mathrm{~N}$; and $38 \mathrm{E}, 66 \mathrm{~N}$. 


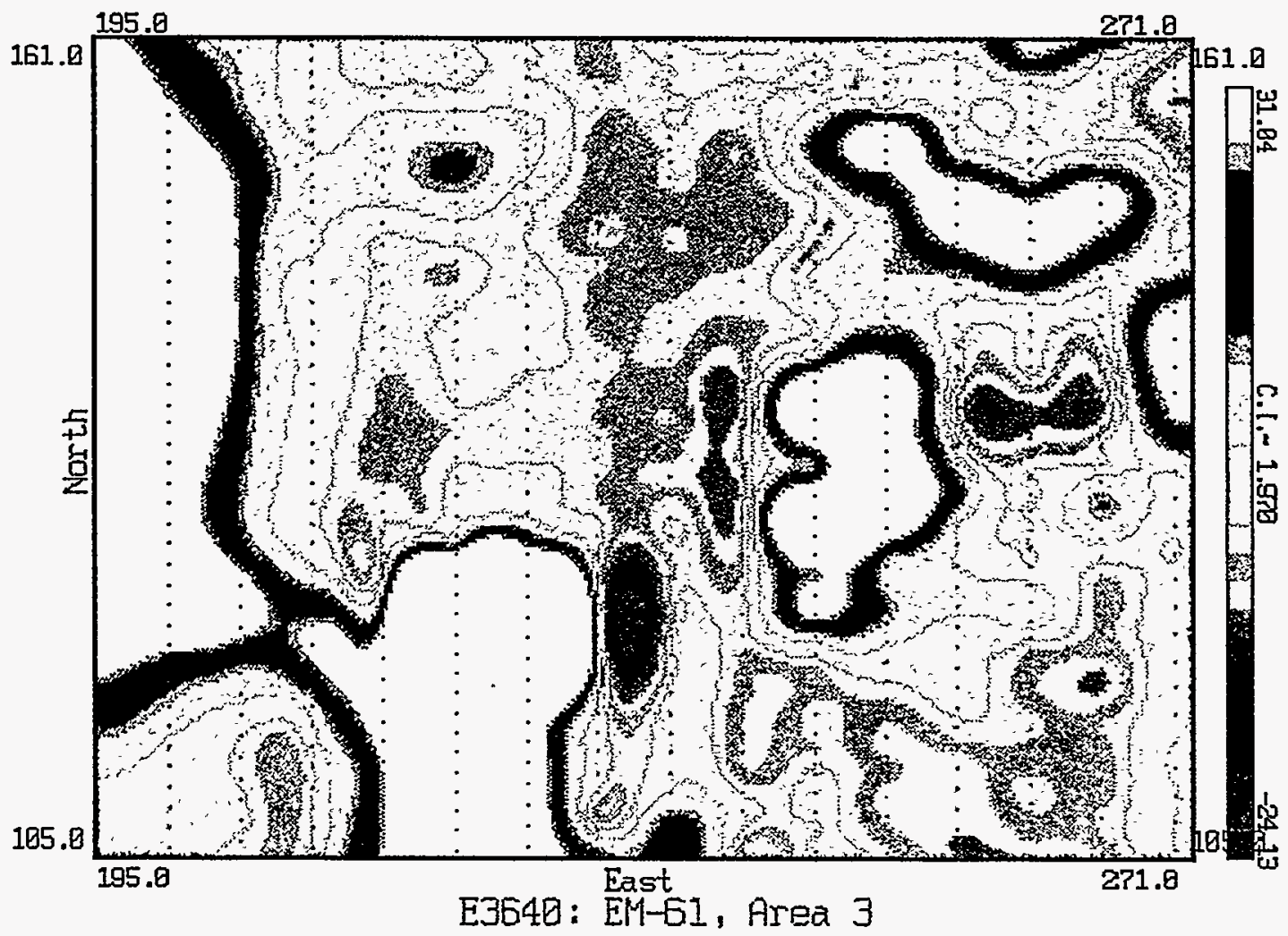

FIGURE 18 EMFs in Area 3

\subsection{Ground-Penetrating Radar Measurements}

Ground-penetrating radar profiling was carried out during February and July 1994. A total of 41 individual profiles were collected around the Building E3640 complex. Appendix B contains a complete listing of the GPR profiles collected.

Before production lines for the survey were run at Building E3640, replicate runs were made over the same lines to determine which of the two transceivers (the 100 - or $300-\mathrm{MHz}$ antenna) provided the best results. Following these preliminary tests, the $300-\mathrm{MHz}$ antenna was selected because of its better penetration and resolution.

Four profiles were collected in the bistatic mode (4- $\mathrm{ft}$ antenna separation) around the outside of the fence. These profiles were collected at a range setting of $200 \mathrm{~ns}$ at a scan rate of 32 scans/s. The maximum depth of penetration was approximately $25 \mathrm{ft}$, based on a two-way travel time of $8 \mathrm{~ns} / \mathrm{ft}$. The bistatic profiles were designed to help provide some information regarding deeper geological features beneath the site. These profiles did not reveal any geologic structure or anthropogenic feature of significance. 
- 


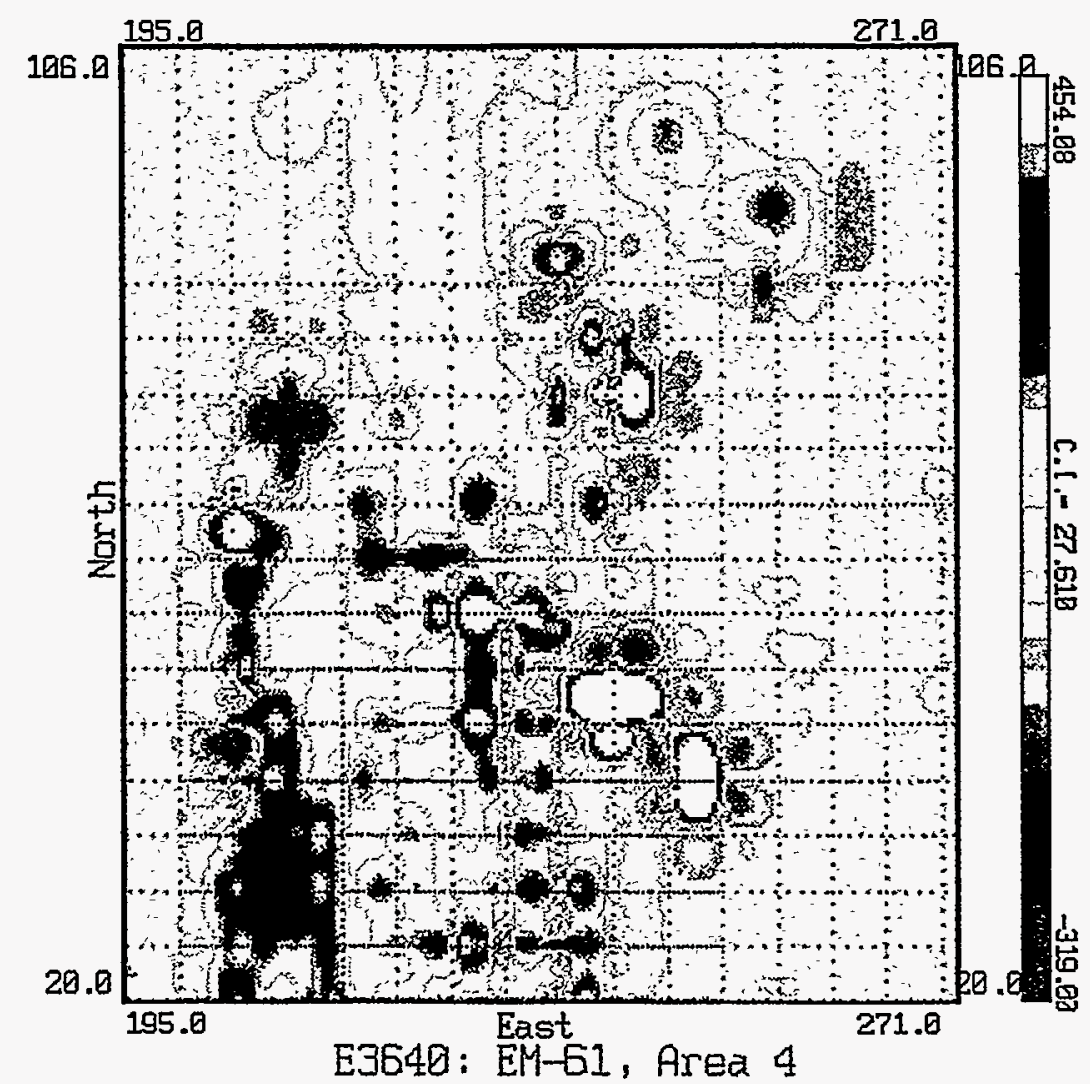

FIGURE 19 EMFs in Area 4

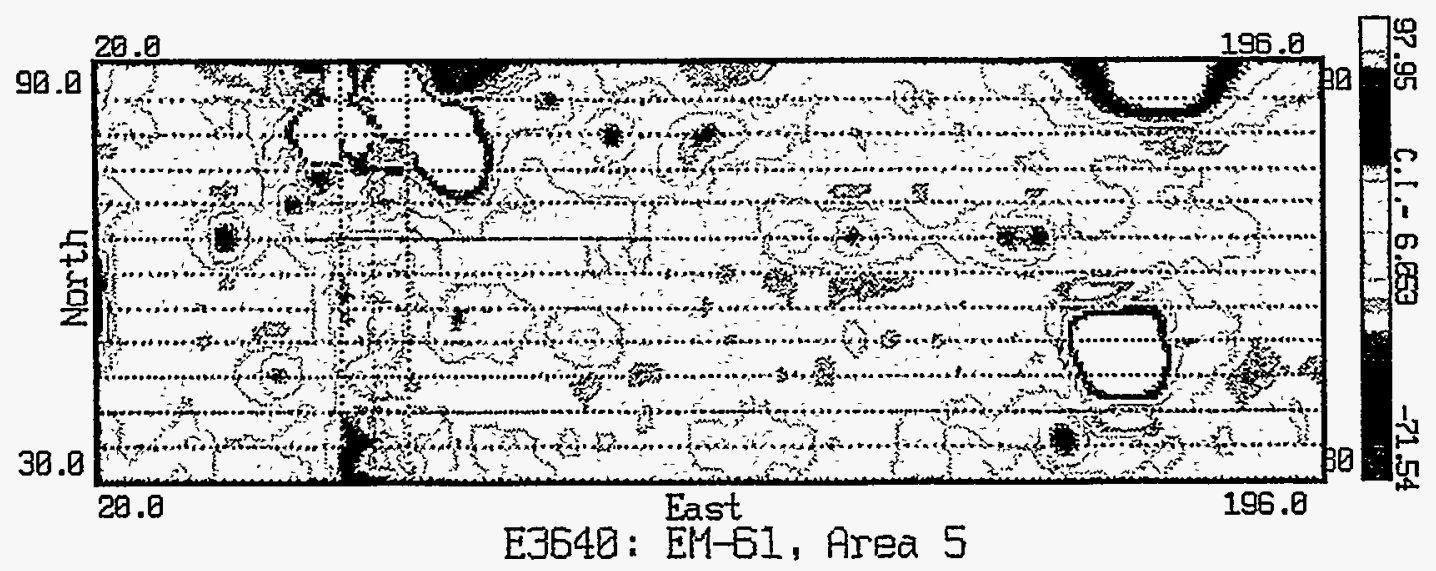

FIGURE 20 EMFs in Area 5 
Thirty-seven GPR profiles were collected inside the fence in the monostatic mode. These profiles were collected at a range setting of $60 \mathrm{~ns}$ with a scan rate of $32 \mathrm{scans} / \mathrm{s}$. Antennas were pulled by hand at a rate of approximately $3 \mathrm{ft} / \mathrm{s}$. These profiles were designed to detect anomalies of anthropogenic origin buried in the upper several feet. The maximum depth of penetration for the monostatic profiles was approximately $7.5 \mathrm{ft}$.

Without verification by using another technique or by passing the antenna over a known object, a quantitative definition of the shape and depth of radar anomalies may only be inferred. Where anomalies are also seen with magnetic or EM profiling, a more definitive description of the feature observed with radar imagery is possible. In the case of the E3640 complex, some correlations with EM and magnetics were observed. For example, radar imagery detected the fire hydrant and sewer lines on the south side of the complex; these were detected in both the magnetic and EM surveys.

The GPR anomaly of greatest significance is located in the northeast corner of the complex. The plastic (polyvinyl chloride) pipe anomaly is apparent in the four profiles in Figure 21. This pipe is most likely the 12-in.-diameter sump drain line discussed in the RCRA Facility Assessment Report, Edgewood Area, Aberdeen Proving Ground, Maryland (Nemeth 1989). Figure 173 from the Nemeth report (shown as Figure 22 in this report) shows the drain line in roughly the same location as shown by the GPR data plotted in Figure 22 (a, b, c, and d). This drain line is reportedly constructed of plastic and was therefore not detected in the magnetics or EM data. The GPR profile in Figure 21 also shows a second pipe at grid coordinates $242 \mathrm{E}$ and $220 \mathrm{~N}$; this pipe may be a floor drain line for the drum storage rack that connects to the sump drain line. 


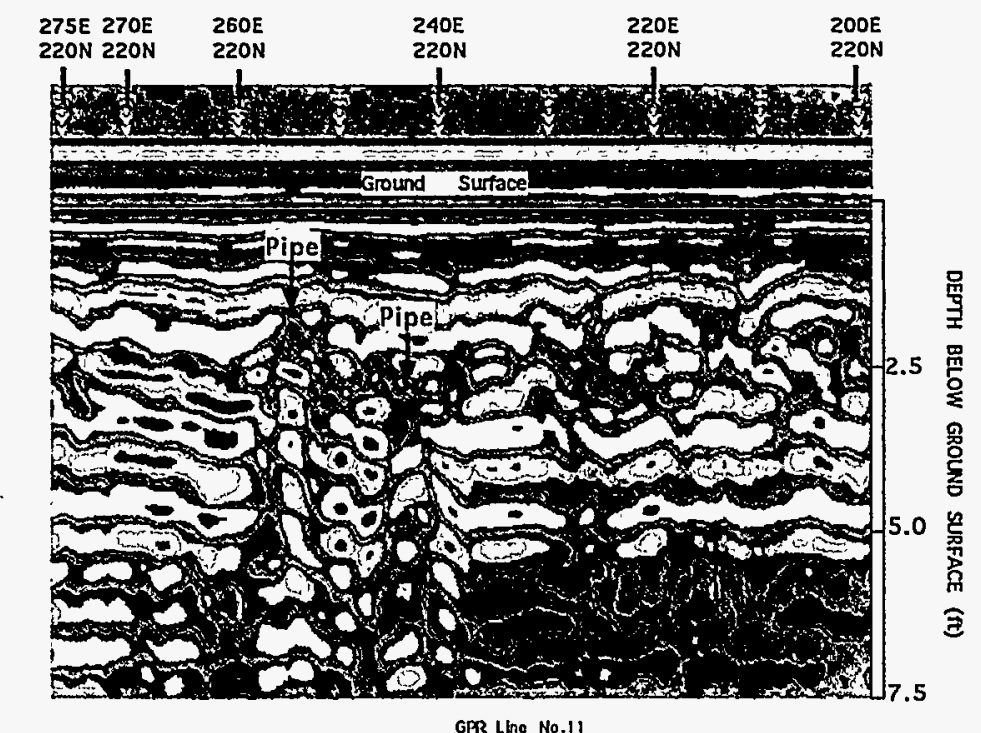

GPR Lino No.11

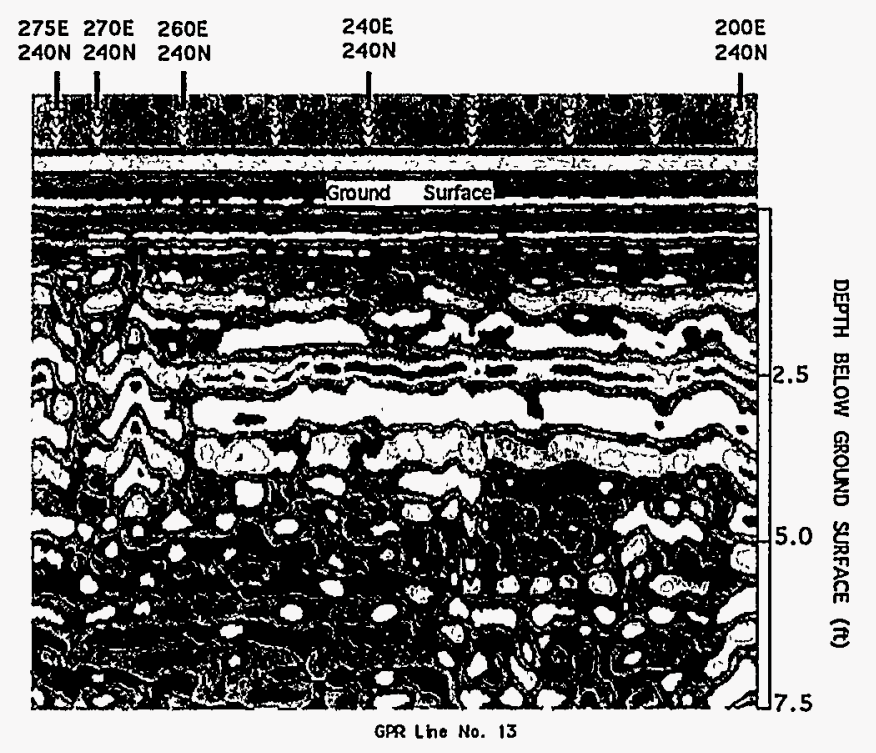

FIGURE 21 Ground-Penetrating Radar Profiles (a, b, c, d)

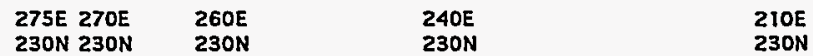

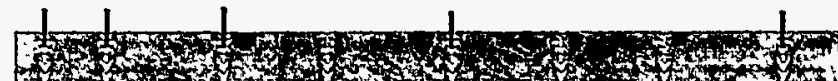

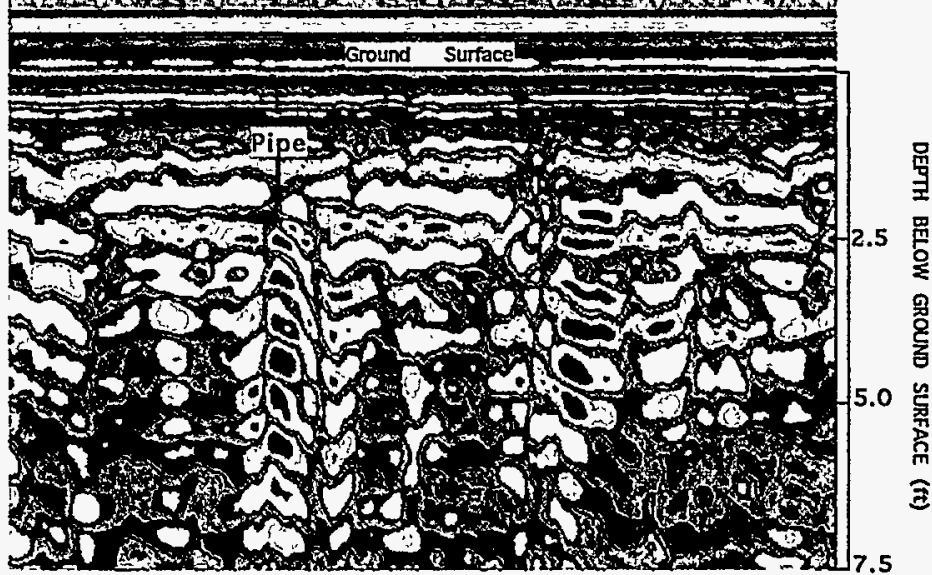
GPR Lino No. 12

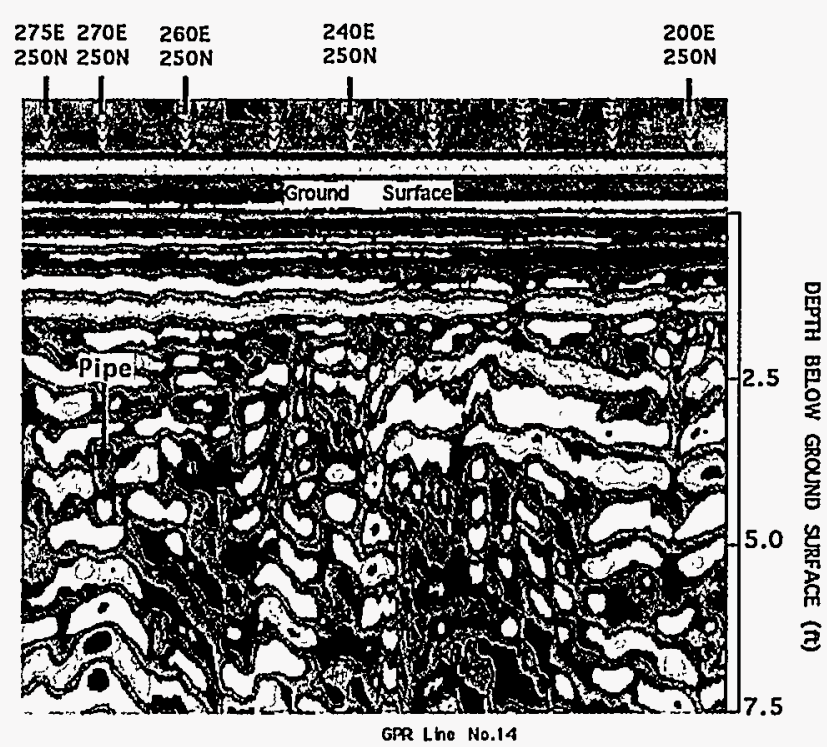




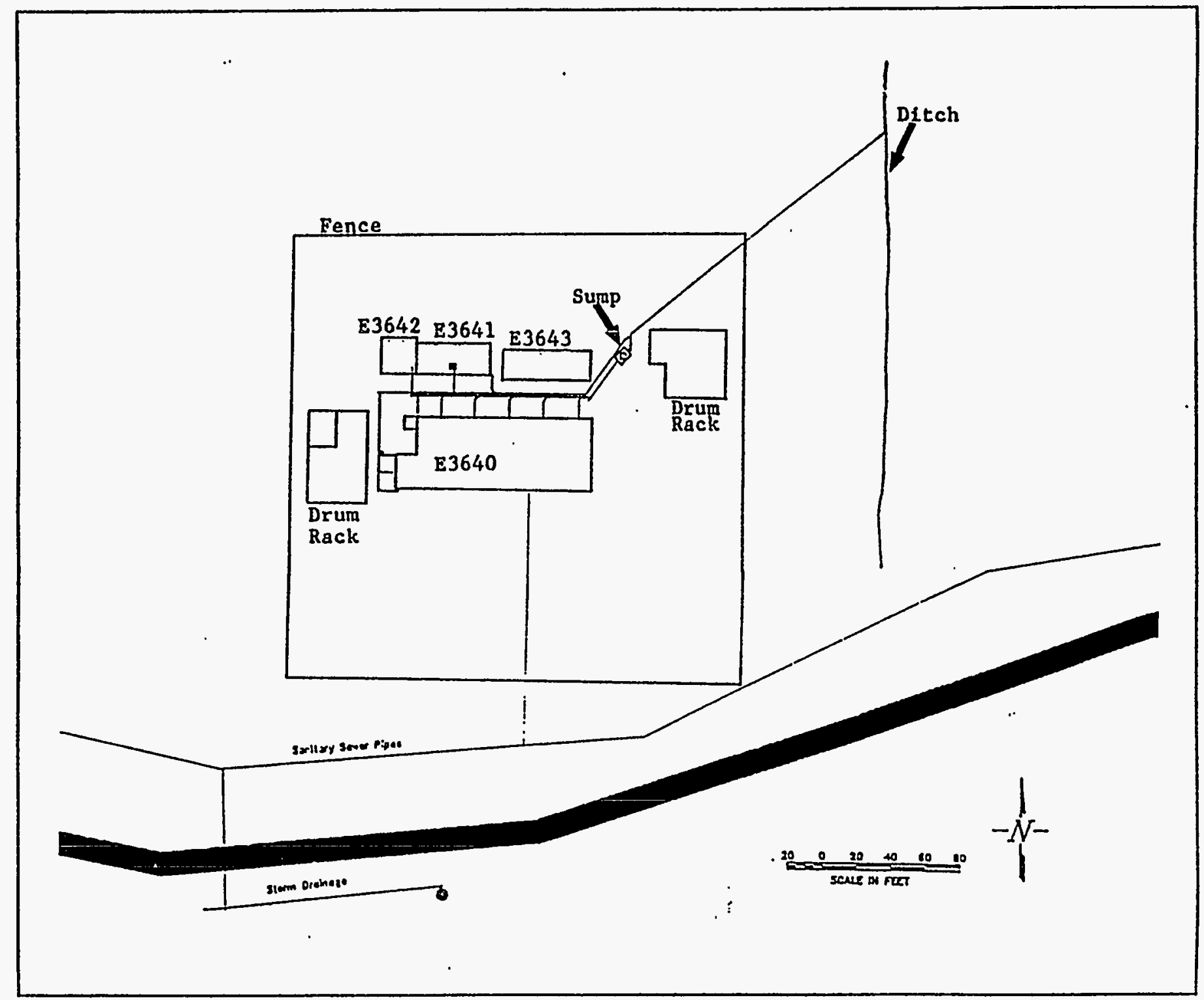

FIGURE 22 Underground Utilities in the Building E3640 Complex (Source: Nemeth 1989) 


\section{Discussion}

Environmental geophysics studies were conducted outside the buildings and around the perimeter of the security fence encompassing the E3640 complex between February and July 1994. The buildings in the E3640 complex were used as a chemical processing facility from 1952 to 1978. Noninvasive surveys, including magnetics, EM-31, EM-61, and GPR, were conducted to detect and map potential contaminant sources, including pipes, tanks, waste water lines, and trenches.

In a 1989 environmental site assessment, Nemeth indicates that no underground storage tanks are present in the E3640 complex. In support of this conclusion, none were observed as a result of the geophysical studies conducted between February and July 1994. A subsurface chemical waste water disposal system located along the northern border of the building complex drains into sumps and, ultimately, into a 12-in.-diameter waste water line. The waste water line extends $190 \mathrm{ft}$ from a sump at the northeast corner of E3640 to a drainage ditch outside the northeast corner of the security fence surrounding the complex. This line, and sewer lines draining to the south that were used to collect waste water from showers and toilets, were imaged with GPR (see Figure 21). The sewer system drains into a 6-in.-diameter line approximately $150 \mathrm{ft}$ east of the western fence.

Magnetic and electrical interference produced by buildings and aboveground metal obscures many smaller anomalies produced by subsurface sources. In addition, amphibolitic gravel used as road bed and fill material is electrically conductive and magnetic and also obscures many features buried beneath the gravel. For this reason, the 12 -in.-diameter chemical waste water line draining to the north was not imaged with EM-31. The conductivity lineament usually associated with trenching for a nonmetallic pipe was masked by overlying fill. Water lines leading to hydrants from Beach Point Road are observed on both the EM-61 and magnetic maps.

Localized magnetic anomalies from unknown sources and their coordinates are listed in Section 3.1. 


\section{Conclusions}

Site geophysical surveys were conducted around the old "Pilot Complex," including Buildings E3640, E3641, E3642, E3646, to locate subsurface lineaments and point sources. All buried liquid waste lines and fresh water lines were imaged by using one or more of the techniques. No buried tanks were observed during the surveys; however, the point sources remain unidentified. Major geophysical anomalies produced by subsurface features are described below:

1. An EM-61 and EM-31 lineament, caused by a water line, extends north from the south fence to a hydrant southwest of the southwest corner of E3640. An EM-61 anomaly caused by overhead pipes, an apparent continuation of the first anomaly, extends north to the north fence.

2. A broad positive magnetic anomaly north of the material and drum storage area and northeast of E3640 is caused by magnetic fill.

3. A 30-ft-wide band of EM-31 anomalies extends from the front gate to the southeast corner of E3640. This band of anomalies is caused by road bed material, underground utilities, and an aboveground security fence.

4. An EM-61 anomaly is produced by buried utilities coincident with the EM-31 anomaly described in (3) above.

5. GPR images were observed on three lines extending $190 \mathrm{ft}$ northeast from a sump at the northeast corner of E3640 to the eastern fence.

Smaller, unidentified, localized anomalies were observed throughout the survey area. 


\section{References}

EAI Corporation, 1989, Historical Records Search and Site Survey of Edgewood Area Buildings, Final Report, prepared by EAI Corporation, Abingdon, Maryland, for U:S. Army Chemical Research, Development, and Engineering Center, Aberdeen Proving Ground, Md., Contract No. DAA15-87-D-0021, Task 021.

Geonics Limited, 1994, personal communication from Miro Bosnar, Geonics Limited, Mississauga, Ontario, Canada.

Geophysical Survey Systems, Inc., 1987, Operations Manual for Subsurface Interface Radar (SIR System-3), GSSI, North Salem, N.H.

Golden Software, Inc., 1991, Surfer Version 4, Golden, Colo.

McGinnis, L.D., and S.F. Miller, 1991, Interim Progress Report - Geophysics: Building E5032 Decommissioning, Aberdeen Proving Ground, report ANL/ESD/TM-20, Argonne National Laboratory, Argonne, Ill.

McGinnis, L.D., et al., 1992, Interim Progress Report - Geophysics: Building E5440 Decommissioning, Aberdeen Proving Ground, ANL/ESD/TM-42, Argonne National Laboratory, Argonne, $\mathrm{Il}$.

McGinnis, M.G., et al., 1992a, Interim Progress Report - Geophysics: Building E5375 Decommissioning, Aberdeen Proving Ground, ANL/ESD/TM-37, Argonne National Laboratory, Argonne, $\mathrm{Il}$.

McGinnis, M.G., et al., 1992b, Interim Progress Report - Geophysics: Building E5974 and E5978 Decommissioning, Aberdeen Proving Ground, ANL/ESD/TM-47, Argonne National Laboratory, Argonne, Ill.

Miller, S.F., et al., 1992a, Interim Progress Report - Geophysics: Building E5190 Decommissioning, Aberdeen Proving Ground, ANL/ESD/TM-33, Argonne National Laboratory, Argonne, $\mathrm{Ill}$.

Miller, S.F., et al., 1992b, Interim Progress Report - Geophysics: Building E5476 Decommissioning, Aberdeen Proving Ground, ANL/ESD/TM-43, Argonne National Laboratory, Argonne, $\mathrm{Il}$.

Munsell Soil Color Charts, 1975, Macbeth, a division of Kollmorgen Corporation, Baltimore, Md. 
Nemeth, G., 1989, RCRA Facility Assessment Report, Edgewood Area, Aberdeen Proving Ground, Maryland, 21010-5422, No. 39-26-0490, United States Army Environmental Hygiene Agency, Aberdeen Proving Ground, Md.

Oliveros, J.P., and P. Gernhardt, 1989, Hydrogeologic Data for the Canal Creek Area, Aberdeen Proving Ground, Maryland, April 1986-March 1988, U.S. Geological Survey, Open File Report 89-387.

Thompson, M.D., et al., 1992a, Interim Progress Report - Geophysics: Building E5282 Decommissioning, Aberdeen Proving Ground, ANL/ESD/TM-36, Argonne National Laboratory, Argonne, $\mathrm{Ill}$.

Thompson, M.D., et al., 1992b, Interim Progress Report - Geophysics: Building E5481 Decommissioning, Aberdeen Proving Ground, ANL/ESD/TM-44, Argonne National Laboratory, Argonne, $\mathrm{Il}$. 


\section{Appendix A:}

Building E3640 History and Characteristics from Nemeth 1989 


\section{Appendix A:}

\section{Building E3640 History and Characteristics - from Nemeth 1989}

The Building E3640 Process Laboratory is located north of Beach Point Road, south of Kings Creek, and southwest of the Building E3700 Complex. The original number designation for this structure was Building 2345 (E3640).

1. The Building E3640 Process Laboratory was, as its name implies, a facility used for process laboratory work. This process laboratory was constructed in 1951 and 1952, opened in 1952, and was actively used until 1978.*

a. Building 2345 (E3640) is a four-floor structure approximately $40 \mathrm{ft} \times 115 \mathrm{ft}$ in size. It is constructed of corrugated transite on a steel frame with a concrete floor/foundation. The north side of each floor has five working bays in which experimental work was performed. These bays were numbered 1 through 5, from east to west. Most of the bays contained hoods or chambers, and were ventilated with exhaust from bays 4 and 5 on each floor going through a caustic scrubber unit. The ventilation exhaust from bays 1 through 3 was vented directly to the atmosphere. Steam, water, and electricity were provided by outside lines, and there was no on-site heating plant or fuel oil tanks.

b. Supporting facilities which were part of the Building E3640 Process Laboratory facility included Building 2345C (E3643), an office, electronics shop, and storage building; Building 2345A (E3641), the caustic scrubber structure and equipment; Building 2345B (E3642), a storage facility and the location of a caustic tank for the scrubbing system; and material storage areas west and northeast of Building 2345 (E3640). The material storage area northeast of Building 2345 (E3640) was principally a drum rack which had a concrete floor, was partially roofed, and was open-sided. The other material storage area (E3646) also had a concrete floor and was partially roofed. Building 2345C (E3643) was demolished circa 1981. All of the other structures still exist.

c. The chemical waste water system ${ }^{* *}$ for the Building E3640 Process Laboratory collected waste water from the working bays in the north side of

* While the Building 2345 (E3640) facility was not used as a process laboratory after 1978, the facility was used for storage of some materials until approximately 1986 or 1987.

** The significance of this exposure pathway depends greatly on the degree and extent of soil contamination in the area. It is likely that soil contamination is very localized and primarily associated with possible points of release, such as storage sites and waste water systems. 
Building 2345 (E3640) and from the caustic scrubbers in Building 2345A (E3641). Most of the bay areas in Building 2345 (E3640) contained floor and/or hood drains with piping which were a part of this chemical waste water system. There are at least five small concrete below-the-floor sumps on the first floor of Building 2345 (E3640). The chemical waste water system has underground lines which carry waste water from each bay area north to connect with a 6-in. east-west line which is located roughly $10 \mathrm{ft}$ north of Building 2345 (E3640). This 6-inch waste water line entered a flow-through sump located northeast of the northeast corner of Building 2345 (E3640) and east of Building 2345C (E3643). The caustic scrubber building has a below-floor waste water sump, and waste water from the scrubbers was carried by 4-in. underground lines to the east-west line north of 2345 (E3640) and south of 2345A (E3641), which flowed to the sump. Effluent from the sump was via a 6-in. line which connected with the storm drain system for the Building 2345 (E3640) area immediately north of the sump. Discharge was then through a 12-in. VC line into an open ditch at a point approximately $190 \mathrm{ft}$ northeast of the sump. The open ditch carried the waste water northward to a marsh area associated with Kings Creek.

d. The sanitary waste water system for the Building E3640 Process Laboratory includes showers, sinks, and toilets on the south side of the first floor, with a 6-in. line connecting to the sanitary sewer system directly south of Building 2345 (E3640).

e. Chemical storage for the Building E3640 Process Laboratory was at the two areas west and northeast of Building 2345 (E3640). The storage at these two areas was of drummed material and smaller containers stored in conex containers. Materials storage was also within Building 2345 (E3640) itself. Temporary storage of solid wastes prior to disposal would have been at these same sites. Storage of caustic solution for the scrubber system was in an approximately 3000 gallon tank located in Building 2345B (E3642). There was no on-site disposal (burial, burning, etc.) of solid wastes at the Building E3640 Process Laboratory.

f. Most liquid waste materials generated at the Building E3640 Process Laboratory were disposed of in the chemical waste water system. Solid waste materials such as contaminated gloves, glassware, and solid chemical wastes were normally drummed or otherwise packaged and then picked up and disposed of by the USATEU. This ultimate disposal would have been at the toxic disposal pits in either O-field or J-field.

g. The Building E3640 Process Laboratory facility was one of the sites at which it was alleged in a recent criminal case that there was storage of hazardous wastes without a permit. These charges related to the storage of 
chemical materials at the facility after its closure as an R\&D facility in 1978, until the mid to late 1980s.

h. The identified SWMUs at the Building E3640 Process Laboratory facility are the storage areas within and west and northeast of Building 2345 (E3640), at which wastes were temporarily stored until disposal; the Building 2345 (E3640) waste water system including below-floor sumps and the exterior below-ground flow-through sump; and the caustic scrubber system including the sump in Building 2345A (E3641).

i. The Building E3640 Process Laboratory is currently abandoned, and it is the intent of APG and CRDEC to demolish and dispose of the facilities.

2. Chemical materials handled in the Building E3640 Process Laboratory include essentially all of the standard US military chemical agents, those post-WWII experimental agents which were produced on a process laboratory or larger scale, miscellaneous other materials such as B-1 dye, and the manufacturing raw materials and intermediates of these materials. Solid and liquid wastes would have potentially included these materials and/or their degradation and decontamination products. ${ }^{* * *}$ Most of the work at the Building E3640 Process Laboratory involved preparation of materials or evaluation of production processes. A small amount of the work was research related to disposal of materials. For example, experimental work related to disposal of chemical agent ID sets was performed at this facility.

3. The ground surface elevation above $\mathrm{msl}$ at the Building E3640 Process Laboratory is between 15 and $20 \mathrm{ft}$. Surface water drainage is to the north into a marsh associated with Kings Creek, which is roughly $1000 \mathrm{ft}$ north of the facility. There is no available site specific information concerning geology or ground water. The depth to ground water is expected to be roughly 4 to $8 \mathrm{ft}$. Water table contour maps prepared by the USGS as part of work under the Canal Creek RFI project show a surficial aquifer ground-water divide north of the Building E3640 Process Laboratory, with flow at this unit toward the south. It is possible that the groundwater divide is farther south, and that flow at the unit is toward the north; wells in the immediate vicinity would be necessary to verify flow direction. The possible points of release to the environment at the Building E3640 Process Laboratory include leaking sumps and sewer lines, spillage of chemical material at the material storage sites west

*** The lethal chemical agents would have been largely destroyed by chemical decontamination and would not have been significant constituents of the discharged waste water. 
and northeast of Building 2345 (E3640), and the waste water ditch. ${ }^{* * *}$ There was no documented or known large scale usage of DNAPL materials at this site, and any such materials would probably not reach the waste water ditch because of the sumps in the waste water system. The potential contaminant migration pathways are shallow ground water and surface water transport of soil. Contaminants could reach the ground water from any of the possible release points. Potential transport of contaminated soil by surface water runoff would relate primarily to the areas adjacent to the material storage sites.

4. Inspection of the Building E3640 Process Laboratory facility as part of this RFA was performed during several visits during the May 1986 through 1989 time period. The only visual evidence of possible hazardous material release to the environment is an area bare of vegetation adjacent to the north side of the drum storage area northeast of Building 2345 (E3640). This area extends downslope, to the north-northeast, from the north side of the concrete drum storage area for a distance of roughly 15 to $20 \mathrm{ft}$. At the time of the inspections there was no release occurring, and no indication through odor or site observation as to the time of release or type of material(s) which had been spilled.

a. A soil sample was collected from the area north of the drum storage site in October 1987. The sample was a composite of the top 3 inches of soil from four locations in a line from the edge of the storage structure to a point approximately $15 \mathrm{ft}$ from the structure. A shovel was used to excavate and break up the soil, and stainless steel tools were then used to take the sample. The surface soil near the structure was dark gray to black in color and had no discernible odor. The soil sample was analyzed for TEP metals, pesticides/PCBs and semivolatile organic compounds. No TEP metals were detected. Analysis for PCBs revealed the presence of $0.65 \mathrm{mg} / \mathrm{kg}$ Arochlor 1242 and $1.76 \mathrm{mg} / \mathrm{kg}$ Aroclor 1260 . One hazardous semivolatile constituent, 4-nitroaniline, was detected at a concentration of $0.73 \mathrm{mg} / \mathrm{kg}$. Also present in the sample were an unknown compound $(7 \mathrm{mg} / \mathrm{kg}$ ) and compounds tentatively identified as phosphoric acid tris (2-ethylhexyl ester) $(0.44 \mathrm{mg} / \mathrm{kg})$, and dodencanoic acid ester $(0.30 \mathrm{mg} / \mathrm{kg})$. The 4-nitroaniline was used at the Building E3640 Process Laboratory in the experimental formulation of $\mathrm{Bl}$ dye. It is likely that PCBbased oils have been used as process heat transfer fluids and also as fluids in electrical transformers.

b. There are no ground-water monitoring wells in the immediate vicinity of the Building E3640 Process Laboratory. The closest monitoring wells are in

**** There is no information to indicate that the sumps or sewer lines leaked, but leakage of sewer lines at older industrial facilities is common and often a source of ground-water contamination. Even if sewer lines or sumps did not leak, there was almost certainly percolation of waste water from the unlined ditch to ground water along its upper portion near Building 2345 (E3640). 
the vicinity of E3580, roughly $500 \mathrm{ft}$ from E3640, and possibly in a down gradient direction.

c. The water in the sump located northeast of E3640 was sampled 19 November 1986 as part of a waste water characterization study by AEHA addressing APG. No pesticides, PCBs, or base-neutral extractable organic compounds were detected in the sample. Low levels of the volatile organic compounds benzene, chloroform, toluene, tetrachloroethylene, and trichlorofluoromethane were detected. Also detected were the acid extractable organics 2,4-dichlorophenol and phenol. Concentrations of these contaminants ranged from $0.008 \mathrm{mg} / \mathrm{L}$ to $0.40 \mathrm{mg} / \mathrm{L}$.

5. It is recommended that the following actions be taken to address the Building E3640 Process Laboratory:

a. As an interim remedial action, remove the contaminated topsoil adjacent to the north side of the drum storage area northeast of Building 2345 (E3640). The cleanup should initially involve removing visually stained soil at the site, roughly the top 6 inches of soil in, and immediately adjacent to, the area bare of vegetation. After this removal, limited soil sampling should be accomplished to ensure that high levels of contamination do not remain.

b. In another interim remedial action, sample and remove material from sumps associated with the Building E3640 Process Laboratory. This recommendation includes the large sump northeast of E3640 and smaller sumps within E3640. Method of sludge and water disposal will be dependent on sampling and analysis results.

c. Collect and analyze composite sediment samples from the drainage ditch into which the Building E3640 Process Laboratory Chemical waste water system discharged. Three composite samples should be collected, one up gradient of the discharge, and two samples down gradient. The samples should be analyzed for total and TEP metals, pesticides/PCBs, and semivolatile organic compounds.

d. Review the objectives of the ongoing Canal Creek RFI project. If project objectives include addressing all potential sources of ground water contamination, the work should be expanded to include addressing the Building B3640 Process Laboratory. Such work would probably include the installation of monitoring wells screened in the surficial aquifer at three or four locations. Depending on the thickness of the surficial aquifer at this site, it may be necessary to install more than one well at some of the sites. 
Appendix B:

Ground-Penetrating Radar Line Coordinates for Building E3640 
Appendix B:

Ground-Penetrating Radar Line Coordinates for Building E3640

\begin{tabular}{|c|c|c|c|c|}
\hline \multirow[b]{2}{*}{ Line \# } & \multicolumn{2}{|c|}{ Start Coordinates } & \multicolumn{2}{|c|}{ End Coordinates } \\
\hline & North & East & North & East \\
\hline $\begin{array}{l}1{ }^{*} \\
2 \\
3 \\
4 \\
5 \\
6 \\
7 \\
8 \\
9 \\
10 \\
11 \\
12 \\
13 \\
14 \\
15 \\
16 \\
17 \\
18 \\
19 \\
20 \\
21 \\
22 \\
23 \\
24 \\
25 \\
26 \\
27 \\
28 \\
29 \\
30 \\
31 \\
32 \\
33 \\
34 \\
35 \\
36 \\
37 \\
38 \\
39 \\
40 \\
41 \\
\\
9 \\
\end{array}$ & $\begin{array}{r}0 \\
280 \\
280 \\
0 \\
10 \\
10 \\
10 \\
15 \\
50 \\
100 \\
220 \\
230 \\
240 \\
250 \\
250 \\
260 \\
20 \\
25 \\
30 \\
35 \\
40 \\
45 \\
50 \\
55 \\
60 \\
65 \\
70 \\
75 \\
80 \\
80 \\
85 \\
90 \\
95 \\
100 \\
105 \\
110 \\
105 \\
105 \\
75 \\
120 \\
145\end{array}$ & $\begin{array}{r}290 \\
000 \\
000 \\
0 \\
230 \\
240 \\
250 \\
215 \\
215 \\
210 \\
275 \\
275 \\
275 \\
275 \\
10 \\
10 \\
15 \\
12 \\
12 \\
12 \\
12 \\
12 \\
12 \\
12 \\
12 \\
12 \\
12 \\
12 \\
12 \\
12 \\
12 \\
145 \\
12\end{array}$ & $\begin{array}{r}280 \\
280 \\
0 \\
0 \\
120 \\
120 \\
170 \\
15 \\
50 \\
100 \\
220 \\
230 \\
240 \\
250 \\
250 \\
260 \\
20 \\
25 \\
30 \\
35 \\
40 \\
45 \\
50 \\
55 \\
60 \\
65 \\
70 \\
75 \\
80 \\
80 \\
80 \\
90 \\
95 \\
100 \\
105 \\
110 \\
15 \\
15 \\
15 \\
15 \\
0\end{array}$ & $\begin{array}{r}290 \\
290 \\
000 \\
285 \\
230 \\
240 \\
250 \\
275 \\
275 \\
275 \\
200 \\
200 \\
200 \\
200 \\
100 \\
100 \\
200 \\
200 \\
200 \\
200 \\
200 \\
200 \\
200 \\
200 \\
170 \\
170 \\
170 \\
200 \\
70 \\
200 \\
200 \\
200 \\
200 \\
155 \\
155 \\
155 \\
200 \\
60 \\
110 \\
150 \\
200\end{array}$ \\
\hline
\end{tabular}

- Lines 1-4 were collected in the bistatic mode $(300 \mathrm{mHz})$ at a range $=200 \mathrm{~ns}$.

* * Lines 5-41 were collected in the monostatic mode $(300 \mathrm{mHz})$ at a range $=60 \mathrm{~ns}$. 